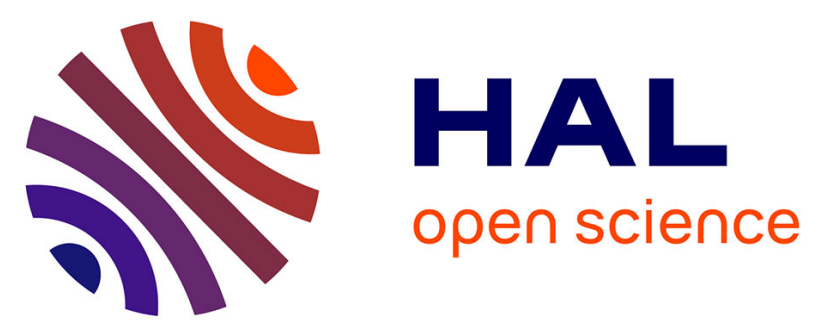

\title{
New insight of the influence of acidic surface sites of zeolite on the ability to remove gaseous ozone using operando DRIFTS studies
}

Héctor Valdés, Francisco J Ulloa, Víctor A Solar, Manuel S Cepeda, Federico Azzolina-Jury, Frederic Thibault-Starzyk

\section{To cite this version:}

Héctor Valdés, Francisco J Ulloa, Víctor A Solar, Manuel S Cepeda, Federico Azzolina-Jury, et al.. New insight of the influence of acidic surface sites of zeolite on the ability to remove gaseous ozone using operando DRIFTS studies. Microporous and Mesoporous Materials, 2020, 294, pp.109912. 10.1016/j.micromeso.2019.109912 . hal-02419105

\section{HAL Id: hal-02419105 \\ https://hal.science/hal-02419105}

Submitted on 25 Oct 2021

HAL is a multi-disciplinary open access archive for the deposit and dissemination of scientific research documents, whether they are published or not. The documents may come from teaching and research institutions in France or abroad, or from public or private research centers.
L'archive ouverte pluridisciplinaire $\mathbf{H A L}$, est destinée au dépôt et à la diffusion de documents scientifiques de niveau recherche, publiés ou non, émanant des établissements d'enseignement et de recherche français ou étrangers, des laboratoires publics ou privés. 
New insight of the influence of acidic surface sites of zeolite on the ability to remove gaseous ozone using operando DRIFTS studies

Héctor Valdés ${ }^{1, *}$, Francisco J. Ulloa ${ }^{1,2}$, Víctor A. Solar ${ }^{1}$, Manuel S. Cepeda ${ }^{2}$, Federico Azzolina-Jury ${ }^{3}$, Frédéric Thibault-Starzyk ${ }^{4}$

${ }^{1}$ Laboratorio de Tecnologías Limpias, Facultad de Ingeniería, Universidad Católica de la Santísima Concepción, Concepción, Chile.

${ }^{2}$ Departamento de Ingeniería Industrial, Facultad de Ingeniería, Universidad Católica de la Santísima Concepción, Concepción, Chile.

${ }^{3}$ Normandie Université, ENSICAEN, UNICAEN, CNRS, Laboratoire Catalyse et Spectrochimie, 14000, Caen, France.

${ }^{4}$ Maison Française d'Oxford, CNRS, MEAE, 2-10 Norham Rd, Oxford OX2 6SE, United Kingdom.

*Corresponding author. Tel.: +56-41-2345044; fax: +56-41-2345300; 
E-mail address: hvaldes@ucsc.cl (H. Valdés)

\begin{abstract}
Recently, natural zeolites have started to be used as alternative materials for ozone abatement from working environments. In this study, a surface response methodology based on a DOptimal design is applied to develop a transition-metal-modified natural zeolite that increases ozone removal efficiency. Ozone adsorption and/or decomposition onto natural and cobalt modified natural zeolite were studied by diffuse reflectance infrared Fourier transform spectroscopy (DRIFTS). Results evidenced that ozone is adsorbed and decomposed at strong Lewis acidic sites, whereas ozone adsorption products interact with surface $\mathrm{OH}$ groups. Additionally, DRIFTS studies indicate that nitrous species are adsorbed at acidic sites, reducing the capacity to decompose ozone when ozone is generated from air.
\end{abstract}

Keywords: DRIFTS; Natural zeolite; Ozone; Surface acid sites; Transition metals. 


\section{Introduction}

Ozone at tropospheric level poses serious environmental and occupational health hazards. Ozone can increase sensitivity to bronchoconstrictors and allergens, and may facilitate the development of asthma. In working environments, ozone is formed by laser printers, photocopiers, sterilization apparatus and ozone generators for air and water treatment [1]. Cars and power plant emissions are precursors of ozone outdoor formation [2].

Thermal destruction, adsorption and catalytic decomposition have been the main processes used to mitigate the emissions of ozone and keep air quality standards [3]. In a thermal ozone destruction unit, the offgas is heated between $300^{\circ} \mathrm{C}$ and $350^{\circ} \mathrm{C}$ for less than $5 \mathrm{~s}$. In this system gases are discharged at these elevated temperatures being of environmental concern [3]. Activated carbons have been applied to remove gaseous ozone [4, 5]. However, it is not presently recommended. Reaction of ozone with dry activated carbon generates a considerable heat and may be explosive [3]. Moreover, both physical and chemical properties of activated carbon change along ozone exposition time [4]. Therefore, more resistant materials such as metal oxide catalysts have been developed for ozone elimination [6-12]. Nevertheless, the high investment costs become a major obstacle for full-scale application and alternative materials should be found.

Recently, low cost stable natural zeolites have been used as alternative materials not only for gaseous ozone elimination but also in the removal of volatile organic compounds using a sequential treatment based on the adsorption onto natural zeolite followed by its oxidative regeneration with ozone [13-15]. Lewis acid sites were claimed as the main active sites for ozone gaseous elimination in outgassed natural zeolite at $550^{\circ} \mathrm{C}$ [14]. Transition metal modified natural zeolites could act as an alternative and low cost catalyst to effectively abate ozone, exhibiting greater activities than the parent natural zeolite. This research faces such challenges. 
This work provides experimental basis for scaling up and designing a catalytic process to remove ozone emissions from working environments, using transition-metal-modified natural zeolites at low temperature. In particular, the impact of the structure, the framework composition, and the identity of the transition-metal-modified natural zeolites on the catalytic activity in the gaseous ozone abatement are established. Finally, a mechanism for the catalytic $\mathrm{O}_{3}$ removal reaction over transition-metal-modified natural zeolite is proposed.

\section{Material and Methods}

\subsection{Materials}

Natural zeolite (NZ) was provided by the Chilean mining company "Minera Formas". NZ was ground and sieved to $0.300-0.425 \mathrm{~mm}$; then was rinsed with ultra pure water, oven-dried at $125{ }^{\circ} \mathrm{C}$ for $24 \mathrm{~h}$, and stored in a desiccator until its further use. This solid is composed of clinoptilolite (53\%), mordenite (40\%), and quartz (7\%) [16]. NZ was chemically and thermally modified by a succession of ion-exchange with ammonium salt at $90^{\circ} \mathrm{C}$, thermal out-gassing, and metal deposition, to obtain the transition metal-modified natural zeolites ( $\mathrm{Z}$ Mt) as reported in previous publication [17]. $\mathrm{Cu}, \mathrm{Mn}, \mathrm{Ag}, \mathrm{Co}, \mathrm{Fe}$, and Ni were used here as active transition metals (Mt) for natural zeolite modification. They were supplied in the form of metal salts by MERCK (Darmstadt, Germany) as: copper nitrate $\left(\mathrm{Cu}\left(\mathrm{NO}_{3}\right)_{2} \cdot 3 \mathrm{H}_{2} \mathrm{O}\right)$, manganese sulphate $\left(\mathrm{MnSO}_{4} \mathrm{H}_{2} \mathrm{O}\right)$, silver nitrate $\left(\mathrm{AgNO}_{3}\right)$, cobalt nitrate $\left(\mathrm{Co}\left(\mathrm{NO}_{3}\right)_{2} \cdot 6 \mathrm{H}_{2} \mathrm{O}\right)$, ferric nitrate $\left(\mathrm{Fe}\left(\mathrm{NO}_{3}\right)_{3} \cdot 9 \mathrm{H}_{2} \mathrm{O}\right)$ and nickel nitrate $\left(\mathrm{Ni}\left(\mathrm{NO}_{3}\right)_{2} \cdot 6 \mathrm{H}_{2} \mathrm{O}\right)$ (all with purity > 99\%). After that, zeolite samples were thermally post-treated, reaching the same final temperature of thermal out-gassing procedure conducted in the step before $\left(350^{\circ} \mathrm{C}\right.$ or $\left.550^{\circ} \mathrm{C}\right)$, as indicated elsewhere [17]. All post-treatments of the deposited metals were performed in a vertical tubular furnace. Zeolite samples were loaded in quartz U-shaped fixed-bed flow contactors. A 
group of samples were out-gassed under argon flow $\left(100 \mathrm{~cm}^{3} \min ^{-1}\right)$, heated at $10{ }^{\circ} \mathrm{C} \min ^{-1}$ and isothermal conditions were kept for $2 \mathrm{~h}$, before quenching to room temperature. The remaining samples were calcined under oxygen flow $\left(100 \mathrm{~cm}^{3} \mathrm{~min}^{-1}\right)$, heated at $1^{\circ} \mathrm{C} \mathrm{min}^{-1}$ and isothermal conditions were kept for $4 \mathrm{~h}$, before quenching to room temperature. Additionally, some calcined samples were further subjected to a reduction post-treatment using $\mathrm{H}_{2}$ at $5 \%$ (v/v) in argon flow $\left(20 \mathrm{~cm}^{3} \mathrm{~min}^{-1}\right)$ with a heating rate of $1{ }^{\circ} \mathrm{C} \mathrm{min}^{-1}$, reaching the final temperature and then cooled to room temperature. After all post-treatment procedures, transition metal-modified natural zeolite samples were ready to contact gaseous ozone. Ozone was produced in situ from dry synthetic air using a pulse injected corona discharge AZCOZON ozone generator (AZCO Industries, Vancouver, BC, Canada) featuring variable ozone generation rates in the concentration range from 9000 to $11000 \mathrm{ppmv}$.

\subsection{Experimental design and optimization by response surface methodology}

Fig. 1 shows, as a flowchart, the strategy used in this work to develop Z-Mt for gaseous ozone abatement at room temperature. A surface response methodology based on a DOptimal design was used to identify the optimum Z-Mt with increased ozone removal efficiency. A D-optimal design with ten factors (five qualitative plus five quantitative) was used to determine the preparation parameters of the Z-Mt samples and the operating process conditions that maximise ozone removal efficiency. Experimental design variables selected in the modification of natural zeolite, together with operating process variables for ozone elimination are listed in Table 1. 


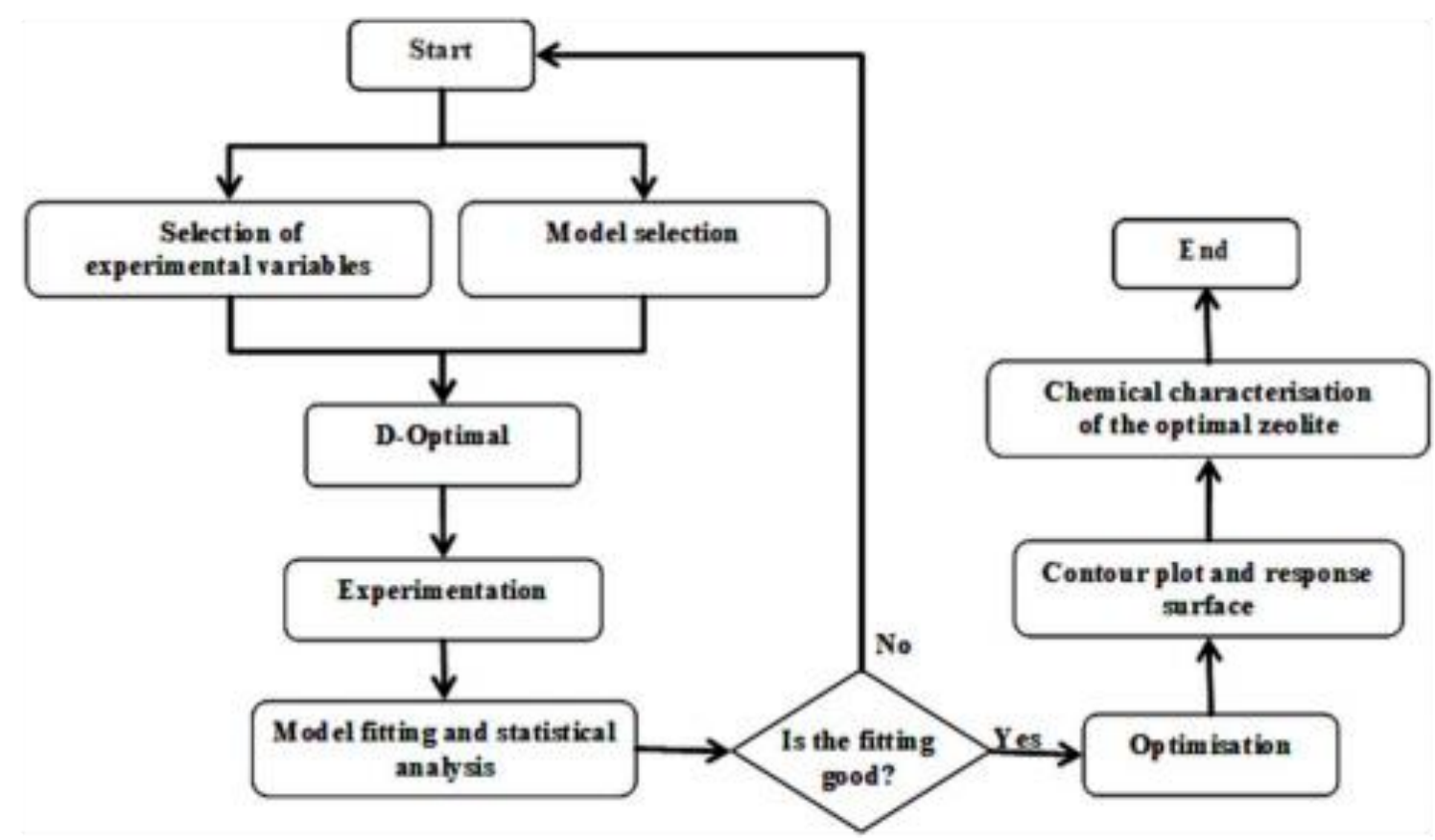

Fig. 1.: Strategy used in the development of a transition-metal-modified natural zeolite

for gaseous ozone removal at room temperature.

Table 1.

Experimental levels of the independent variables.

\begin{tabular}{|c|c|c|c|c|}
\hline \multirow[t]{2}{*}{ Variables } & \multirow[t]{2}{*}{ Symbols } & \multicolumn{3}{|l|}{ Levels } \\
\hline & & Low & Middle & High \\
\hline $\begin{array}{l}\text { Ammonium ion: } \\
\text { exchange }\end{array}$ & $\left(x_{1}\right)$ & one & - & two \\
\hline $\begin{array}{l}\text { Out-gassing temperature } \\
\text { ('C) }\end{array}$ & $\left(x_{2}\right)$ & 350 & - & 550 \\
\hline Type of transition metal & $\left(x_{3}\right)$ & \multicolumn{3}{|c|}{$\mathrm{Ag} \mathrm{Co} \mathrm{Cu} \mathrm{Fe} \mathrm{Mn} \mathrm{Ni}$} \\
\hline $\begin{array}{l}\text { Concentration of } \\
\text { transition metal (mol } \\
\text { dm-3) }\end{array}$ & $\left(x_{4}\right)$ & 0.05 & 0.075 & 0.1 \\
\hline Metal deposition method & $\left(x_{s}\right)$ & $\begin{array}{l}\text { ion- } \\
\text { exchange }\end{array}$ & - & impregnation \\
\hline $\begin{array}{l}\text { Post-treatment of the } \\
\text { deposited metal }\end{array}$ & $\left(x_{b}\right)$ & $\begin{array}{l}\text { out: } \\
\text { gassing }\end{array}$ & calcination & reduction \\
\hline $\begin{array}{l}\text { Inlet concentration of } \\
\text { ozone (ppmv) }\end{array}$ & $\left(x_{7}\right)$ & 9000 & 10000 & 11000 \\
\hline $\begin{array}{l}\text { Volumetric flow }\left(\mathrm{cm}^{3}\right. \\
\left.\text { min }^{-1}\right)\end{array}$ & $\left(x_{s}\right)$ & 50 & 75 & 100 \\
\hline Mass of zeolite (g) & $\left(x_{9}\right)$ & 0.15 & 0.225 & 0.3 \\
\hline $\begin{array}{l}\text { Operating temperature } \\
\text { ('C) }\end{array}$ & $\left(x_{n o}\right)$ & 20 & 60 & 100 \\
\hline
\end{tabular}


A second-order multiple linear regression model was selected to identify the variables that influence ozone removal efficiency of Z-Mt, as follows:

$$
R_{O_{3}}=\beta_{0}+\sum_{i=1}^{15} \beta_{i} X_{i}+\sum_{i=1}^{15} \beta_{i i} X_{i i}^{2}+\sum_{i=1}^{14} \sum_{j=i+1}^{15} \beta_{i j} X_{i} X_{j}+\varepsilon
$$

where $R_{O_{3}}$ is the response variable defined here as the ozone removal efficiency of Z-Mt $(\%)$. $\beta_{0,} \beta_{i,} \beta_{i i}$ and $\beta_{i j}$, are regression coefficients for the constant term, linear, second-order, and interaction effects, respectively. $X_{i}$ and $X_{j}$ are coded independent variables and $\varepsilon$ is the residual associated to the experiments. Afterwards, the software package MODDE 10 (Umetrics AB Inc., Umea, Sweden) was applied to generate the D-Optimal design, using the second-order multiple linear regression model. As a result of the D-optimal design, 126 design runs were chosen from a set of 4608 design runs of the full factorial design, including 3 central points. Experimental runs were conducted randomly, in order to avoid any systematic bias in the outcomes. Experimental results were adjusted to the second-order multiple linear model by a multiple regression technique, using the software package MODDE 10. The fitted model was scrutinised by the analysis of variance (ANOVA). $F$-value was used to identify if the variables explain adequately the variation in the data about its mean and if the model is highly significant. The quality of the fitted model and its predictions were evaluated by the adjusted coefficient of determination $\left(R^{2}\right.$ adj $)$. Finally, a reduced model containing only the statistically significant model variables was numerically optimised, maximising the ozone removal efficiency of the Z-Mt. A mixed integer non-linear programming (MINLP) was used in the optimisation process since the number of variables under study is high; and they are qualitative and quantitative. Optimal response values of the maximum ozone removal of Z-Mt $\left(\hat{R}_{O_{3}}\right)$ were estimated by numerical optimisation using LINGO 11.0 (LINDO Systems Inc., Chicago, USA). The software MODDE 10 was also used 
here to generate response surfaces as a way to illustrate the interaction effects among variables on the ozone removal efficiency of Z-Mt.

\subsection{Experimental procedures}

Experiments were carried out in an U-type fixed-bed flow reactor at 20,60 or $100^{\circ} \mathrm{C}$ loaded with $0.15 ; 0.225$ or $0.3 \mathrm{~g}$ Z-Mt. In regular tests, the reactor was continuously fed with 50,75 or $100 \mathrm{~cm}^{3} \mathrm{~min}^{-1}$ at $\mathrm{STP}$ of an $\mathrm{O}_{2} / \mathrm{O}_{3}$ gas mixture with a concentration of 9000,10000 or 11000 ppmv $\mathrm{O}_{3}$. Ozone concentration in the reactor outlet stream was monitored on-line using an ozone analyser BMT 963 (BMT Messtechnik GmbH, Berlin, Germany), until the effluent concentration of gaseous ozone reached stationary state. Ozone removal efficiency was calculated when the reactor reached the stationary state condition, taking into account the inlet and outlet ozone concentrations.

\subsection{Acidic characterisation of natural and modified Z-Mt zeolite}

The acidic character of NZ and Z-Mt samples was measured by ammonia temperatureprogrammed desorption $\left(\mathrm{NH}_{3}\right.$-TPD). Firstly, $0.15 \mathrm{~g}$ of sample was out-gassed under argon flow $\left(50 \mathrm{~cm}^{3} \mathrm{~min}^{-1}\right)$ and was heated up to $110^{\circ} \mathrm{C}\left(3^{\circ} \mathrm{C} \mathrm{min}^{-1}\right.$ heating rate $)$. In order to minimise physical adsorption, saturation was conducted at $110^{\circ} \mathrm{C}$. Then, $\mathrm{NH}_{3}$ was injected over the samples until reaching saturation. After that, the excess of gas was flushed out using argon $\left(100 \mathrm{~cm}^{3} \mathrm{~min}^{-1}\right)$ until quenching at room temperature. Finally, the adsorbed $\mathrm{NH}_{3}$ was desorbed in a TPD apparatus, coupled with a thermal conductivity detector (TCD) by heating up the samples to $550^{\circ} \mathrm{C}$ at a rate of $3^{\circ} \mathrm{C} \mathrm{min}^{-1}$ in argon flow $\left(100 \mathrm{~cm}^{3} \mathrm{~min}^{-1}\right)$. The conductivity changes of the evolved gas were plotted against temperature. The different temperature ranges in which $\mathrm{NH}_{3}$ was desorbed could be directly related to the acid strength distribution. 
The total amount of chemisorbed $\mathrm{NH}_{3}$ was expected to be proportional to the number of acidic sites per unit mass of the adsorbent [18-20].

2.5 DRIFTS study of surface interactions among natural and modified Z-Mt zeolite samples with ozone

Diffuse reflectance infrared Fourier transform spectroscopy (DRIFTS) was applied to distinguish the chemical interaction features that take place between surface sites of the NZ and of the optimum Z-Mt samples and $\mathrm{O}_{3}$ generated from pure oxygen and from dry synthetic air.

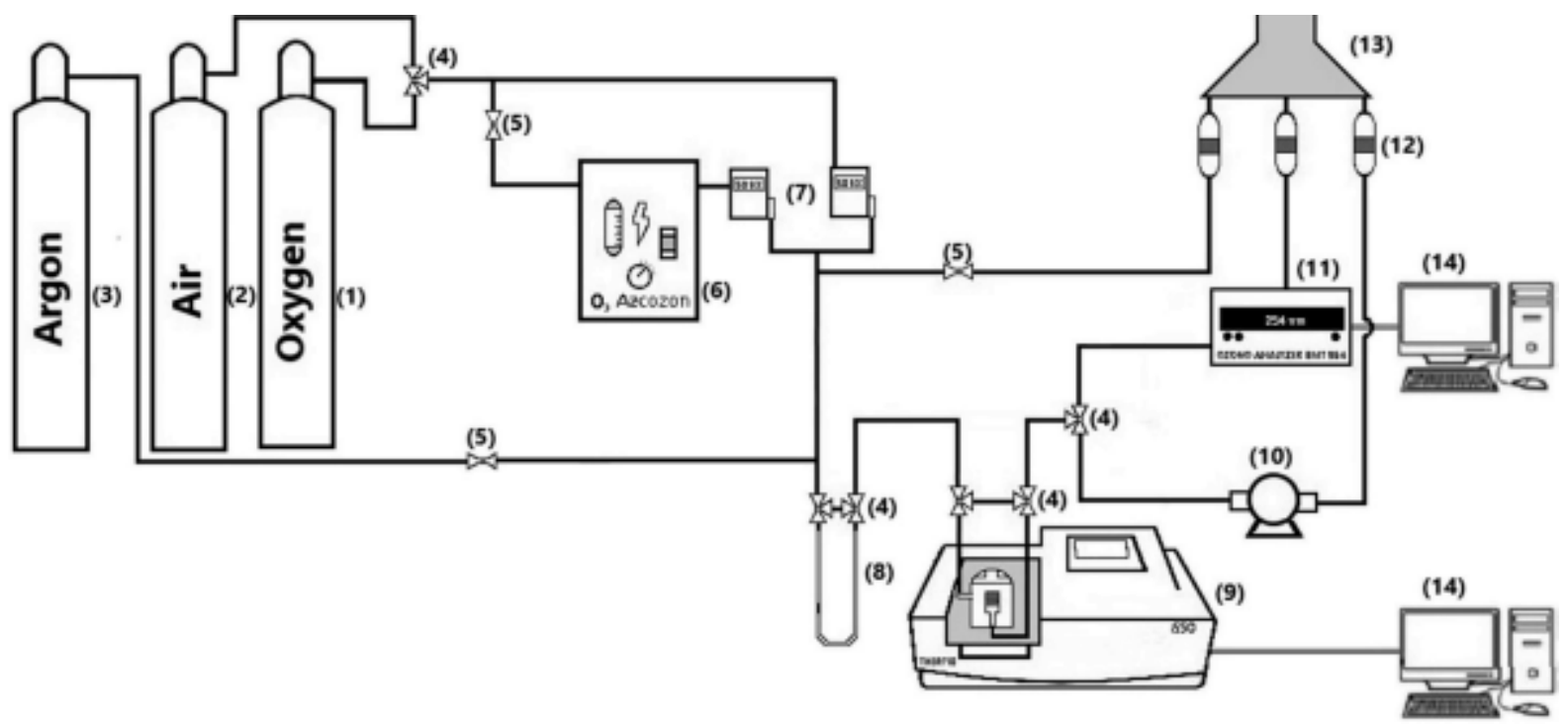

Fig. 2: Experimental setup for ozone removal using natural and modified zeolite sample at room temperature: (1) oxygen cylinder, (2) air cylinder, (3) argon cylinder, (4) three way valve, (5) needle valve, (6) AZCOZON ozone generator, (7) mass flow controller, (8) U-type fixed bed reactor, (9) PIKE DiffusIR ${ }^{\mathrm{TM}}$ reaction cell set in a Nicolet $^{\mathrm{TM}}$ iSTM $^{\mathrm{TM}}$ spectrometer, (10) vacuum pump, (11) BMT ozone analyser, (12) Kraft cellulose trap, (13) extractor hood, (14) computer. 
DRIFTS operando studies were performed using a commercial DRIFTS cell (PIKE DiffusIR $\left.{ }^{\mathrm{TM}}\right)$, with a $\mathrm{KBr}$ window $(32 \times 3 \mathrm{~mm})$ and a gas flow system set on a Nicolet $^{\mathrm{TM}}$ iS ${ }^{\text {TM} 50 ~ s p e c t r o m e t e r ~(T h e r m o ~ F i s h e r ~ S c i e n t i f i c ~ I n c ., ~ U S A) ~ e q u i p p e d ~ w i t h ~ a ~ D T G S ~ d e t e c t o r ~}$ (see Fig. 2). NZ or Z-Mt was loaded into a ceramic cup with a porous base. After that, the loaded cup was placed into the PIKE DiffuIR ${ }^{\mathrm{TM}}$ chamber. The signal measured on a mirror was used as reference. Before the measurement, the sample was post-treated inside the chamber following the optimal levels of preparation parameters obtained after the optimisation procedure. Then, the sample was cooled down to $20^{\circ} \mathrm{C}$ under vacuum $\left(3 \times 10^{-3}\right.$ $\mathrm{hPa}$ ) and a spectrum of the sample without ozone was measured. Spectra were collected as an average of 30 scans with a resolution of $1 \mathrm{~cm}^{-1}$ between 4000 and $720 \mathrm{~cm}^{-1}$. In operando DRIFTS studies ozone was generated not only from dry synthetic air $\left(21 \% \mathrm{O}_{2}\right.$ purity balanced in nitrogen) but also from pure oxygen (99.5\% purity) provided by Air Liquide Chile. In both cases, the inlet concentration of ozone was rated at 22000 ppmv.

An $\mathrm{O}_{2} / \mathrm{O}_{3}$ gas mixture was passed through the PIKE DiffuIR ${ }^{\mathrm{TM}}$ chamber during $60 \mathrm{~min}$ and spectra were registered as a function of time. At the same time, the concentration of ozone in the reactor outlet stream was registered on-line using a BMT 963 ozone analyser (BMT Messtechnik GmbH, Berlin, Germany). PIKE TempPro ${ }^{\mathrm{TM}}$ software was used for temperature control and data collection. Results were processed with OMNIC 9.0 software.

\section{Results and Discussion}

\subsection{Experimental design and optimization by response surface methodology}

Experimental results were adjusted to a second-order multiple linear regression model (Eq. 1). Table 2 lists the results of the analysis of variance (ANOVA) of the fitted second-order multiple linear model. 
Table 2.

ANOVA results of the adjusted second-order multiple linear regression model.

\begin{tabular}{|c|c|c|c|c|c|}
\hline Source & $\begin{array}{l}\text { Sum of } \\
\text { squares }\end{array}$ & $\begin{array}{l}\text { Degree of } \\
\text { freedom }\end{array}$ & $\begin{array}{l}\text { Mean } \\
\text { square }\end{array}$ & F-value & p-value \\
\hline Model & 175,938 & 115 & $1,543.32$ & $35.0062^{\pi}$ & $<0.0001$ \\
\hline Residual & 484.958 & 11 & 44.09871 & & \\
\hline $\begin{array}{l}\text { Lack of } \\
\text { fit }\end{array}$ & 477.89 & 9 & 53.0988 & 15.025 & 0.064 \\
\hline $\begin{array}{l}\text { Pure } \\
\text { error }\end{array}$ & 7.06807 & 2 & 3.53403 & & \\
\hline Total & 176,423 & 126 & $1,411.39$ & & \\
\hline
\end{tabular}

ANOVA results show that the adjusted model is highly significant with a $p$-value < 0.0001. Computed $F$-value $\left(\mathrm{F}_{0.05(115.11)}=35.0062\right)$ shows a much greater value than the tabular $F$-value $\left(\mathrm{F}_{0.05(115.11) \text { tabular }}=2.45\right)$ with a significance level of $5 \%$. Hence, the obtained Fisher $F$-value ensures that the variables under study describe adequately the data variation about its mean and also indicates that the estimated factor effects are important $[21,22]$. Moreover, the $F$-value (15.025) associated to the analysis of model's lack of fit shows to be insignificant relative to the pure error with a $p$-value of $0.064>0.05$, indicating the good predictability of the fitted model. Additionally, the value of the determination coefficient $\left(R^{2}\right)$ shown in Table 2, indicates that the variability in the response on the ozone removal efficiency of Z-Mt could be explained in a $99.7 \%$ by the model. The adjusted determination coefficient $\left(R_{a d j}^{2}=0.969\right)$ turns to be also high, indicating a high significance of the model and a good fit among the regression model and the experimental values.

The fitted regression model with the most significant coefficients ( $p$-value less than 0.05 ) is presented in Eq. (2). The significance of each coefficient in the regression model was analysed using the $p$-values. 


$$
\begin{aligned}
& R_{O_{3}}=59.7+10.43 X_{3 N i}-13.53 X_{3 F e}+18.54 X_{3 C o}+12.44 X_{3 M n}-13.90 X_{3 A g}+2.51 X_{6 \mathrm{Cal}}+3.1 X_{6 \mathrm{Re} d} \\
& -2.31 X_{8}+2.92 X_{9}+27.92 X_{10}-16.73 X_{4}^{2}-13.27 X_{8}^{2}-5.67 X_{1} X_{3 M n}+11.11 X_{1} X_{3 \mathrm{Ag}}+2.27 X_{1} X_{4} \\
& -2.76 X_{1} X_{7}-6.51 X_{2} X_{3 M n}+3.43 X_{2} X_{6 \mathrm{Cal}}+2.71 X_{2} X_{8}-5.01 X_{3 N i} X_{4}+6.65 X_{3 N i} X_{6 \mathrm{Cal}}+6.25 X_{3 N i} X_{9} \\
& -11.91 X_{3 F e} X_{10}-7.65 X_{3 C o} X_{6 \mathrm{Cal}}-5.39 X_{3 \mathrm{CO}} X_{7}-7.29 X_{3 \mathrm{Co}} X_{9}+19.14 X_{3 \mathrm{Co}} X_{10}+4.3 X_{3 M n} X_{4} \\
& -4.3 X_{3 M n} X_{5}-3.8 X_{3 M n} X_{8}+14.62 X_{3 M n} X_{10}+5.34 X_{3 A g} X_{9}-13.38 X_{3 \mathrm{Ag}} X_{10}-2.81 X_{4} X_{5}+5.05 X_{4} X_{6 r e d} \\
& +3.24 X_{4} X_{9}-3.32 X_{5} X_{6 \mathrm{Cal}}-3.71 X_{6 \mathrm{Cal}} X_{9}+7.14 X_{6 \mathrm{Cal}} X_{10}+3.27 X_{6 \mathrm{Red}} X_{9}-2.68 X_{8} X_{10}+4.05 X_{9} X_{10}
\end{aligned}
$$

Model assumptions such as, normality, constant variance (homoscedasticity) and independence were verified (see Fig. S1 in supplementary information section). Fig. S1-A, depicts the normal probability of the studentised residuals associated to the experiments. These results indicate that the residuals are normally distributed, since most of the points fall on a straight line. In order to corroborate that the residuals fit a normal distribution, the Kolmogorov-Smirnov (K-S) non-parametric test was performed [23], resulting with a $p$-value $=0.3375$ a statistic $\mathrm{K}-\mathrm{S}=0.0594$. Hence, there is not enough evidence to imply that the residuals do not come from a normal distribution. Fig. S1-B displays the results of homoscedasticity analysis. As it can be seen, the residuals are distributed randomly according to the predicted values of the response and do not follow any type of visual pattern. Thus, from the graphical analysis it is inferred that the variance of the residuals is constant and therefore the assumption of homocedasticity of the model is verified. Fig. S1-C illustrates the analysis of independence of the studentised residuals. In this plot is observed that the residuals follow random patterns, evidencing non correlation among the residuals, confirming the model adequacy. Fig. S1-D presents the observed $\left(R_{O_{3}}\right)$ and predicted $\left(\hat{R}_{O_{3}}\right)$ values of response for ozone removal (\%) using Z-Mt. Observed removal efficiencies are obtained from the experimental runs and the predicted values are calculated based on the fitted model. As it can be seen in Fig. S1-D, all data lie approximately along a straight line, turning out that the statistical fitted model used here is adequate to describe the relation among study 
variables. These results are in agreement with those obtained by the determination coefficient $\left(R^{2}\right)$ and the adjusted determination coefficient $\left(R_{a d j}^{2}\right)$ mentioned above.

Among the modification parameters of zeolite characteristics, the type of transition metal and the post-treatment method of the deposited metal are the most significant. Variables associated to the type of metal have a significant linear dependence ( $p$-value $<0.0001)$. Cobalt $\left(X_{3 C o}\right)$, manganese $\left(X_{3 M n}\right)$ and nickel $\left(X_{3 N i}\right)$ produce a positive effect on ozone removal; in contrast to iron, copper and silver. Moreover, the type of post-treatment method of the deposited metal $\left(X_{6 k}\right)$, the volumetric flow of ozone $\left(X_{8}\right)$, the mass of zeolite $\left(X_{9}\right)$ and the operating temperature $\left(X_{10}\right)$, exhibit significant linear dependence on the response variable. Operating temperature has a strong statistical significance $\left(p\right.$-value $\left.<10^{-11}\right)$. An operating temperature fixed at $100^{\circ} \mathrm{C}$ generates the greatest positive effect on ozone removal. Results also show that metal concentration $\left(X_{4}\right)$ and volumetric flow of ozone $\left(X_{8}\right)$ show significant second-order dependences ( $p$-value $<0.05$ ), generating a negative effect on ozone removal.

Interaction effects among experimental variables on the response variable are also represented in Eq. (2). Results show that mutual variable interactions between ion-exchange with ammonium and silver as a selected metal ( $X_{1} X_{3 A g}$ ), iron as a selected metal and the operating temperature $\left(X_{3 F e} X_{10}\right)$, cobalt as a selected metal and the operating temperature ( $X_{3 C o} X_{10}$ ), manganese as a selected metal and the operating temperature $\left(X_{3 M n} X_{10}\right)$, silver as a selected metal and the operating temperature $\left(X_{3 A g} X_{10}\right)$, and to a lesser extent the posttreatment method by calcination and the operating temperature $\left(X_{6 \text { Cal }} X_{10}\right)$ have a strong statistical significance ( $p$-value $<0.0001$ ) on ozone removal. Positive effects on ozone removal are observed with:

- $\quad$ operating temperature of $100^{\circ} \mathrm{C}$ with cobalt or manganese zeolite (greatest optimum),

- $\quad$ operating temperature of $60^{\circ} \mathrm{C}$ and an iron or silver Z-Mt, 
- $\quad$ an operating temperature of $100^{\circ} \mathrm{C}$ with a Z-Mt calcined in the last step,

- $\quad$ two ion-exchanges with ammonium applied to NZ, later modified with silver.

Furthermore, the coefficient values of all these interactions indicate that such interaction effects should be taken into consideration in ozone removal with Z-Mt. More precise information is obtained after conducting an optimisation procedure.

The global optimum for ozone removal is obtained at the maximum amount of ozone removed per gram of Z-Mt ( $\left.\mathrm{mol} \mathrm{O}_{3} \mathrm{~g}^{-1}\right)$. A mixed integer non-linear programming (MINLP) implemented with the GAMS software and the solver BARON (Sahinidis optimisation group, Pittsburgh, USA) using the reduced model containing only the statistically significant variables shown in Eq. (2) (with a $p$-value $<0.05$ ), predicts a maximum amount of ozone removed per gram of zeolite of $0.474 \mathrm{~mol} \mathrm{O}_{3} \mathrm{~g}^{-1}$. The global maximum amount of ozone removed per gram of zeolite is predicted using Co-modified natural zeolite (Z-Co). Z-Co sample is generated after two ion-exchange pre-treatments using ammonium salt, followed by thermal out-gassing at $350^{\circ} \mathrm{C}$. Where $\mathrm{Co}^{2+}$ ions are deposited by ion-exchange $\left(0.05 \mathrm{~mol} \mathrm{\textrm {dm } ^ { - }}\right.$ ${ }^{3}$ ) and then subjected to a thermal out-gassing post-treatment under argon flow at $350{ }^{\circ} \mathrm{C}$ before conducting the ozone elimination experiment. Optimal predicted operating conditions are $100 \mathrm{~cm}^{3} \mathrm{~min}^{-1}$ of volumetric flow, $9000 \mathrm{ppmv}$ of ozone, using a mass of $0.15 \mathrm{~g}$, at $100^{\circ} \mathrm{C}$. The ability of the model to predict the maximum amount of ozone removed per gram of zeolite was verified empirically under the optimised conditions. Experimental results lead to $0.473 \mathrm{~mol} \mathrm{O}_{3} \mathrm{~g}^{-1}$ which is in agreement with the predicted value $\left(0.474 \mathrm{molO}_{3} \mathrm{~g}^{-1}\right)$, using the optimised values of the model variables.

In order to eliminate gaseous ozone at room temperature using transition-metal-modified zeolite, another optimisation procedure was conducted, fixing now the operating temperature at $20^{\circ} \mathrm{C}$. Optimal levels of variables and parameters that maximise the ozone removal efficiency were obtained using the BARON solver software (see Table 3). Additionally, the 
maximum ozone removal efficiency obtained after the optimisation process was verified empirically at the optimised conditions. Experimental results show an elimination of $62.4 \%$ ozone, in agreement with the predicted value (60\%), using the optimised values of the model variables.

Table 3.

Optimal levels of preparation parameters and operating conditions that maximise ozone removal efficiency at $20^{\circ} \mathrm{C}$.

\begin{tabular}{|c|c|c|}
\hline Variables & Symbols & Optimal level \\
\hline Ammonium ion-exchange & $\left(X_{1}\right)$ & Two \\
\hline Out-gassing temperature $\left({ }^{\circ} \mathrm{C}\right)$ & $\left(X_{2}\right)$ & 350 \\
\hline Type of transition metal & $\left(X_{\supset}\right)$ & cobalt \\
\hline Concentration of transition metal $\left(\mathrm{mol} \mathrm{dm}^{-3}\right)$ & $\left(X_{4}\right)$ & 0.07 \\
\hline Metal deposition method & $\left(\mathrm{X}_{\mathrm{s}}\right)$ & impregnation \\
\hline Post-treatment of the deposited metal & $\left(X_{6}\right)$ & out-gassing \\
\hline Inlet concentration of ozone (ppmv) & $\left(X_{7}\right)$ & 9000 \\
\hline Volumetric flow $\left(\mathrm{cm}^{3} \mathrm{~min}^{-1}\right)$ & $\left(X_{s}\right)$ & 75 \\
\hline Mass of zeolite (g) & $\left(X_{\rho}\right)$ & 0.15 \\
\hline Ozone removal efficiency (96) & $\left(R_{0_{3}}\right)$ & 60 \\
\hline
\end{tabular}

As a way of illustration, Fig. 3 shows ozone removal at $20{ }^{\circ} \mathrm{C}$, with natural zeolite sample (NZ) subjected to two ion exchange with ammonium, thermally out-gassed at $350^{\circ} \mathrm{C}$, modified with cobalt $\left(0.07 \mathrm{~mol} \mathrm{dm}^{-3}\right.$ solution) by impregnation and subsequently thermally out-gassed at $350^{\circ} \mathrm{C}$ (Z-Co), with maximum efficiency at $60 \%$ under optimised operating conditions (gas flow of $75 \mathrm{~cm}^{3} \mathrm{~min}^{-1}$ and an inlet ozone concentration of $9000 \mathrm{ppmv}$ ). The increase in ozone elimination in the presence of $\mathrm{Z}$-Co could be related to ozone interaction with new active sites formed on the modified zeolite surface. 

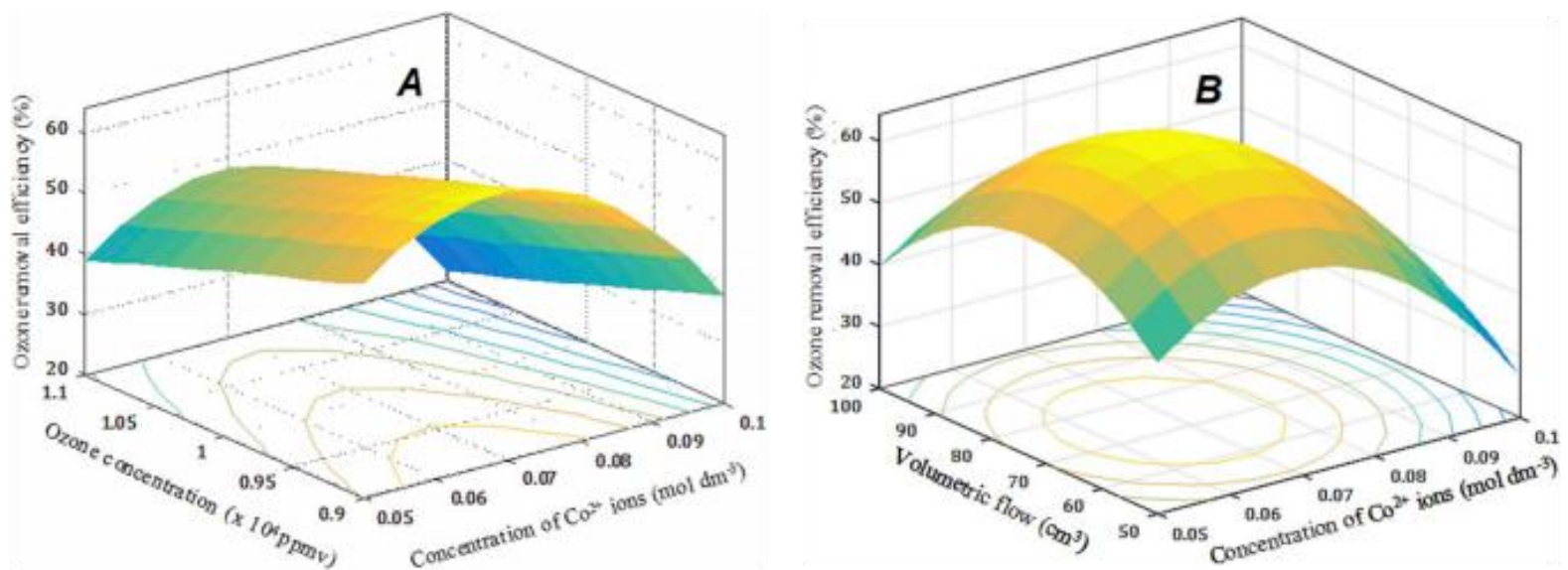

Fig. 3: Response surface on ozone removal using cobalt modified natural zeolite (Z-Co).

(A) Effect of the variation of the inlet concentration of ozone and the concentration of

Co2+ions. (B) Effect of the variation of volumetric flow and the concentration of

Co2+ions. Operating conditions: $0.15 \mathrm{~g}$ of Co-modified natural zeolite, $75 \mathrm{~cm} 3 \mathrm{~min}-1$, at

$20{ }^{\circ} \mathbf{C}$.

3.2 Influence of chemical and thermal modification treatment of natural zeolite on ozone removal

Fig. 4 depicts ozone removal using previously out-gassed $\mathrm{NZ}$ at $350^{\circ} \mathrm{C}$ and Z-Co obtained after chemical and thermal treatment at the experimental conditions described above. In supporting information, XRD results shown in Fig. S2 illustrate that the applied treatments do not cause any significant change in the zeolite crystallinity. Characteristics peaks of clinoptilolite (C), mordenite (M) and quartz (Q) with the same intensity in the diffraction pattern are registered in both zeolite samples. As previously reported, NZ is unable to remove ozone without a thermal pre-treatment $[13,14]$. As Fig. 4 shows, thermal out-gassing of NZ at $350^{\circ} \mathrm{C}$ induces complete ozone removal during the first $100 \mathrm{~min}$, reaching the inlet ozone concentration after 260 min of contact time. A different behaviour is observed when the same ozone stream is put in contact with the Z-Co sample. The concentration of ozone at the reactor outlet stream does not come back to the inlet concentration. These results suggest that 
when Z-Co is used, ozone is not only eliminated by adsorption on the zeolite surface, and a catalytic mechanism is also involved, leading to $c a .63 \%$ ozone removal. The high amount of ozone removed in the presence of Z-Co could be related to new active sites formed after the modification treatment of natural zeolite. A deeper study is necessary in order to reveal the surface reaction mechanism.

Table S2 (see supplementary information) lists the main physical-chemical characteristics of these materials. Surface area $\left(S_{N 2}\right)$, total volume of pores, micropore volume and average pore size were determined from nitrogen adsorption-desorption data at $-196{ }^{\circ} \mathrm{C}$, obtained using a Micrometrics Model ASAP 2020 volumetric adsorption analyser (Norcross, USA) [15]. Additionally, the bulk chemical composition of NZ and Z-Co zeolite samples was determined by X-ray fluorescence (XRF), using a RIGAKU Model 3072 spectrometer [15]. As it can be seen, results indicate that the applied sequence of modification treatments reduce the content of compensating cations, without a significant change on the $\mathrm{Si} / \mathrm{Al}$ ratio of the zeolite framework. The double ammonium sulphate ion-exchange step followed by thermal out-gassing could be responsible of such changes. However, the deposition of $\mathrm{Co}^{2+}$ ions seems to be related to the observed reduction in the value of surface area and pore volume. A redistribution of the cations inside the zeolite framework occurs, limiting the accessibility to nitrogen molecules. 


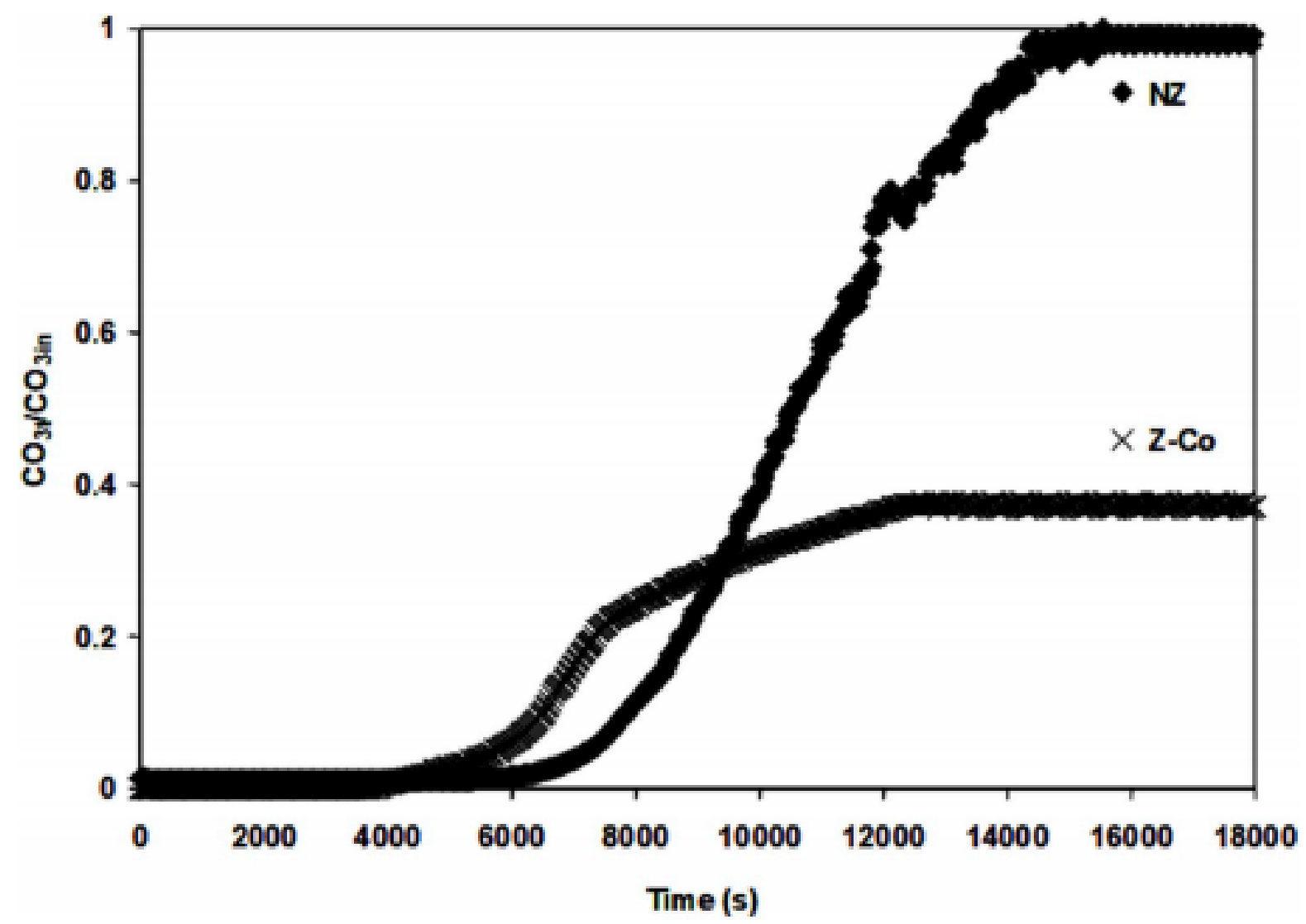

Fig. 4: Influence of chemical and thermal modification treatment of natural zeolite on ozone removal: $\downarrow$ natural zeolite (NZ), $\square$ cobalt modified natural zeolite (Z-Co).

Operating conditions: $0.15 \mathrm{~g}$ zeolite samples, $75 \mathrm{~cm} 3 \cdot \mathrm{min}-1,9000 \mathrm{ppmv}$ of inlet ozone concentration, at $20^{\circ} \mathrm{C}$.

Fig. 5 shows thermal desorption profiles of samples previously saturated with $\mathrm{NH}_{3}$, corresponding to natural zeolite after a thermal out-gassing at $350^{\circ} \mathrm{C}$ (NZ) and cobaltmodified natural zeolite (Z-Co). 


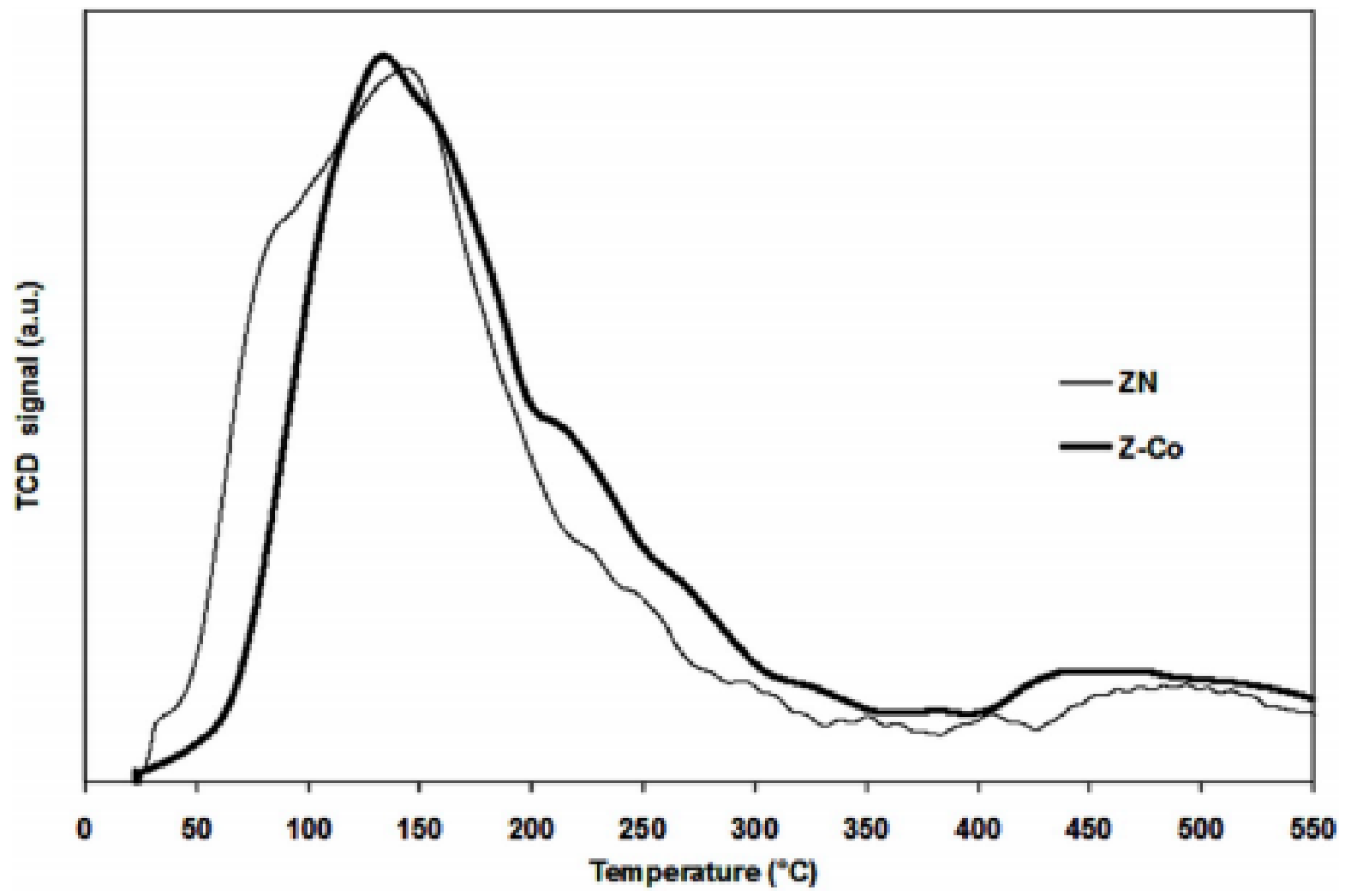

Fig. 5: Acidic surface characterisation using temperature-programmed desorption of ammonia (NH3-TPD). Thin line represents natural zeolite $(\mathrm{ZN})$. Bold line represents cobalt-modified natural zeolite $(\mathrm{Z}-\mathrm{Co})$. Operating conditions: $0.15 \mathrm{~g}$ of zeolite sample, heating up to $550^{\circ} \mathrm{C}\left(3^{\circ} \mathrm{C}\right.$ min-1 heating rate) in argon flow $(100 \mathrm{~cm} 3 \mathrm{~min}-1), 101 \mathrm{kPa}$.

Both samples show similar patterns. During ammonia desorption, two characteristic peaks appear that could be related to the presence of weak and strong acidic sites. The first one is well resolved with a maximum around $145^{\circ} \mathrm{C}$ and a tail that is extended until $350^{\circ} \mathrm{C}$. The second one emerges very slightly at $400^{\circ} \mathrm{C}$ and lengthens to $550^{\circ} \mathrm{C}$. Acidic sites on zeolite surface are due to hydroxyl groups (Brønsted acid sites) and to coordinatively unsaturated (cus) cations (Lewis acid sites) [24]. Mild Lewis sites could be generated upon ionic exchange with transition metals [25]. Molecular ozone could interact with acidic sites of zeolite surface with nucleophilic (Lewis base) character $[15,26]$. 


\subsection{DRIFTS study of ozone interaction with natural and Z-Co zeolite}

In this section, the ozone abatement mechanism onto natural and cobalt natural modified zeolites is unveiled using DRIFTS in operando mode.

The ozone adsorption and decomposition has already been reported on several materials such as $\mathrm{ZrO}_{2}$ [27], $\mathrm{MgO}$ [27], $\mathrm{CeO}_{2}$ [27], $\mathrm{TiO}_{2}$ [27], $\gamma-\mathrm{Al}_{2} \mathrm{O}_{3}[27,28], \mathrm{ZnO}[27,28], \mathrm{CaO}$ [17,28], $\mathrm{ZnO}$ [27], $\alpha-\mathrm{Fe}_{2} \mathrm{O}_{3}[28], \mathrm{CuO}$ [28], $\mathrm{SiO}_{2}$ [29] and synthetic ZSM-5 zeolites using different $\mathrm{Si} / \mathrm{Al}$ molar ratios [30]. In all cases, Lewis acidity showed to play an important role in the ozone adsorption and in its further decomposition. In the case of oxides [17,27-29], the ozone decomposition mechanism takes place through the adsorption of ozone molecules via interaction with hydroxyl groups or via bonding with strong Lewis acidic sites of the metal oxides.

In a previous work [30], we have reported that ozone molecules are eliminated by adsorption on weak acidic sites or by decomposition over strong Lewis acidic sites. In this article, we put in evidence the improvement of ozone abatement by increasing Lewis acidity via Cobalt addition into natural zeolites. Figure 6 shows DRIFTS spectra of natural zeolite (NZ) and cobalt modified zeolite (Z-Co) samples upon contact with gaseous ozone in the region between 4000 and $3300 \mathrm{~cm}^{-1}$. Infrared vibration bands at $3730 \mathrm{~cm}^{-1}, 3700 \mathrm{~cm}^{-1}$, and $3579 \mathrm{~cm}^{-1}$ are observed in both samples. These bands are ascribed to isolated very weakly acidic silanol groups ( $\mathrm{Si}-\mathrm{OH})$, non-acidic aluminic $\mathrm{OH}$ (extra-framework phase), and acidic bridging hydroxyl groups $(\mathrm{Si}(\mathrm{OH}) \mathrm{Al})$, respectively [31,32]. These IR bands are perturbed after zeolite exposure to gaseous ozone due to ozone adsorption in both zeolites. It is important to point out that, before samples exposure to ozone, the amount of acidic surface $\mathrm{OH}$ groups of NZ (Fig. 6-A) is higher than in the case of Z-Co (Fig. 6-B). Brönsted acidity is then lower in the case of Z-Co samples due to metal introduction by ion exchange [33]. 
However, the presence of Cobalt increases the amount of Lewis acidic sites of the natural zeolite $[33,34]$ which has been proved to be crucial in ozone decomposition [30].
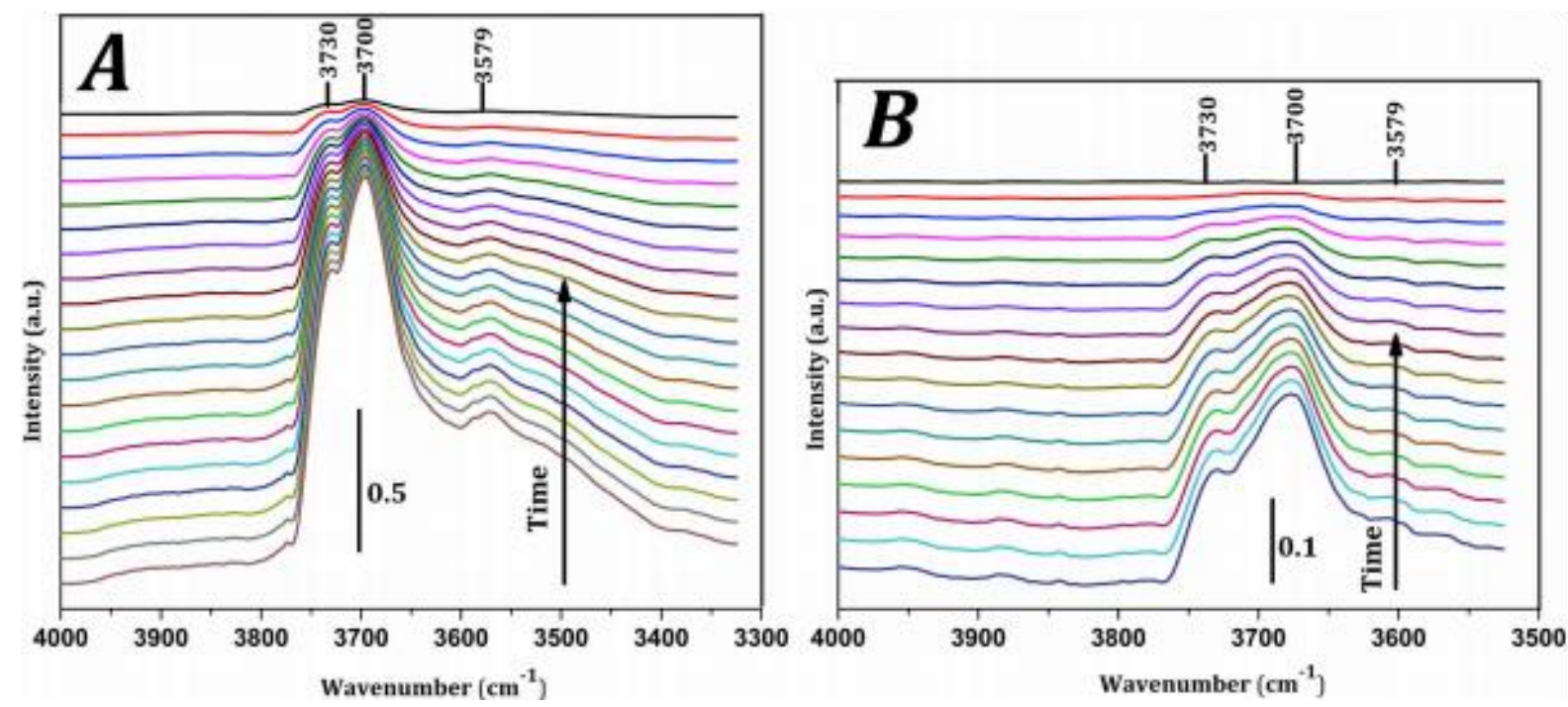

Fig. 6: Evolution of DRIFTS spectra upon zeolites contact with gaseous ozone (generated from pure oxygen) between 4000 and $3300 \mathrm{~cm}-1$ : (A) natural zeolite sample, NZ; (B) cobalt modified zeolite sample, Z-Co. Operating conditions: $30 \mathrm{mg}$ of zeolite sample, $75 \mathrm{~cm} 3 \mathrm{~min}-1$, inlet concentration of ozone $22000 \mathrm{ppmv}$, at $20{ }^{\circ} \mathrm{C}$.

Due to its nucleophilic character, ozone molecule acts as Lewis base. The adsorption and decomposition of ozone at strong Lewis acidic sites can lead to decomposition by-products that can be adsorbed very strongly by H-bonding, even to weak Brönsted sites, causing perturbation of $\mathrm{OH}$ groups and a clearly visible $\mathrm{H}$-bond. This is one of the ways to eliminate ozone using zeolites via physical adsorption through the formation of weak hydrogen bonds with surface $\mathrm{OH}$ groups. This adsorption process is predominant in the case of NZ because of the higher amount of surface acidic $\mathrm{OH}$ groups.

Fig. 7 shows DRIFTS spectra of natural zeolite (NZ) and cobalt modified zeolite (Z-Co) samples upon contact with gaseous ozone in the region between 3300 and $1500 \mathrm{~cm}^{-1}$ as well as the temporal evolution of the IR band at $2125 \mathrm{~cm}^{-1}$. 


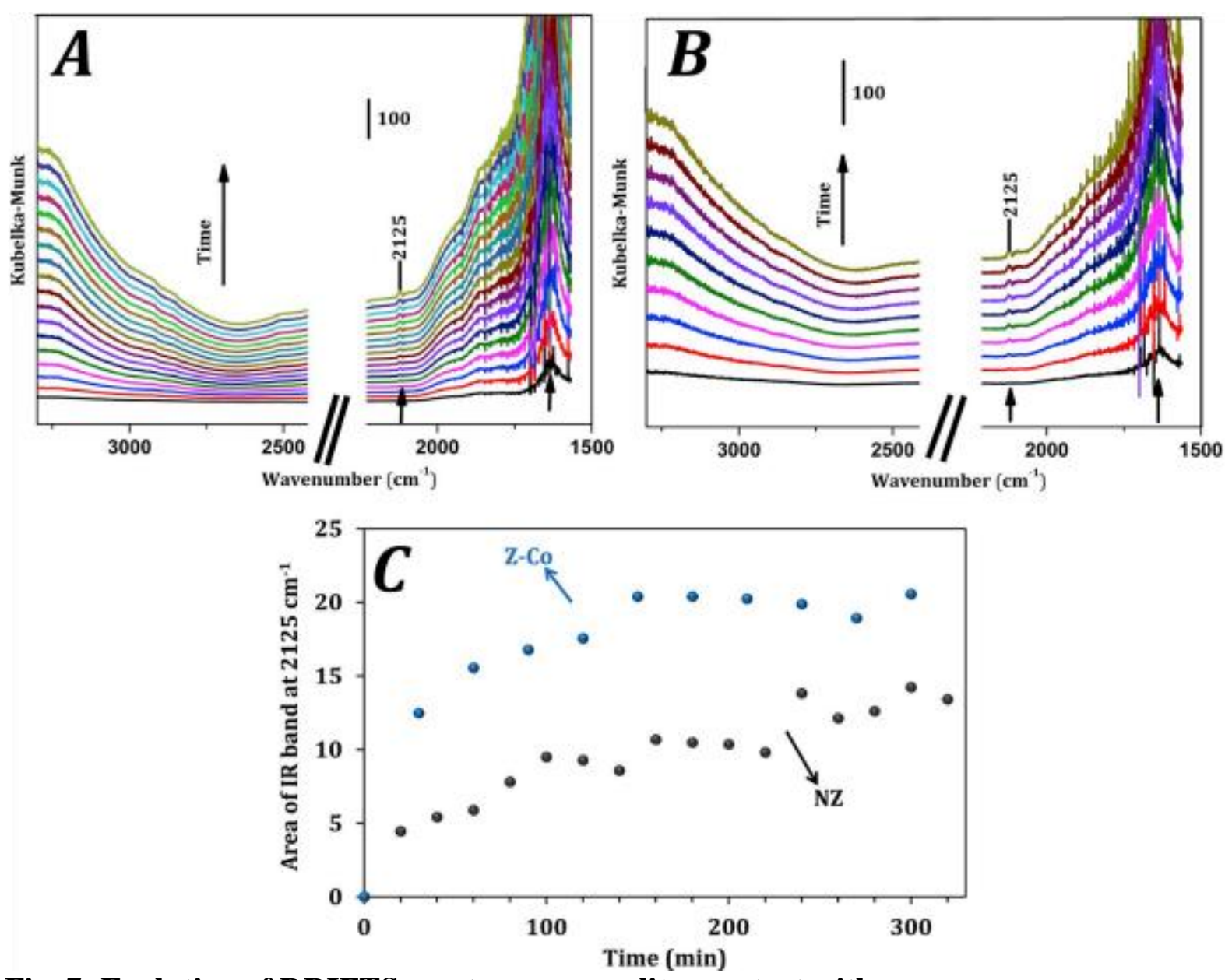

Fig. 7: Evolution of DRIFTS spectra upon zeolites contact with gaseous ozone

(generated from pure oxygen) between 3300 and $1500 \mathrm{~cm}-1$ : (A) natural zeolite sample, NZ; (B) cobalt modified zeolite sample, Z-Co; (C) temporal evolution of the IR band at $2125 \mathrm{~cm}-1$. Operating conditions: $30 \mathrm{mg}$ of zeolite sample, $75 \mathrm{~cm} 3 \mathrm{~min}-1$, inlet concentration of ozone $22000 \mathrm{ppmv}$, at $20{ }^{\circ} \mathrm{C}$.

In agreement with $\mathrm{Wu}$ et al. [28] ozone molecules formed coordinative complexes bound via the terminal oxygen atom, evidenced by vibrational IR frequencies at $2125 \mathrm{~cm}^{-1}$ (Fig. 7) and $1057-1027 \mathrm{~cm}^{-1}$ (shown in Fig. 8) in both samples. It is important to point out that when the initial ozone concentration is decreased 15 times (1400 ppmv), the band at $2125 \mathrm{~cm}^{-1}$ is not observed (result not shown here). In this case, ozone adsorption products interact with 
surface $\mathrm{OH}$ groups. The area of IR bands at $2125 \mathrm{~cm}^{-1}$ is higher in the case of Z-Co compared to NZ (Fig. 7-C). This fact shows that more acidic Lewis sites are available after Co addition, favoring $\mathrm{O}_{3}$ adsorption and the abatement process. Adsorbed water is also observed at 1635 $\mathrm{cm}^{-1}$ and $3250 \mathrm{~cm}^{-1}$ over weak acidic sites (Fig 7). These IR bands increase with ozone contact time and could be formed from decomposition reactions of ozone.

Fig. 8 shows DRIFTS spectra of natural zeolite (NZ) and cobalt modified zeolite (Z-Co) samples upon contact with gaseous ozone in the region between 1400 and $700 \mathrm{~cm}^{-1}$.
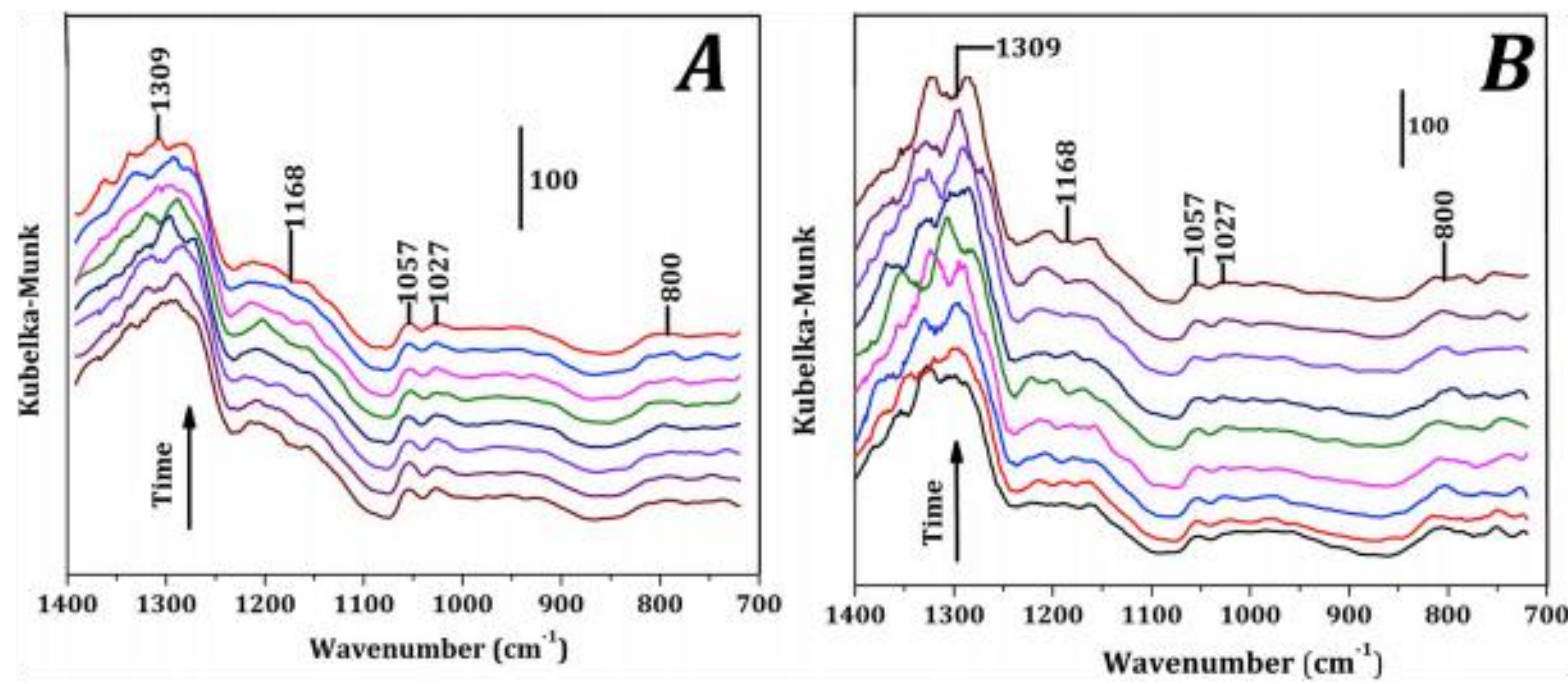

Fig. 8: Evolution of DRIFTS spectra upon zeolites contact with gaseous ozone (generated from pure oxygen) between 1400 and $700 \mathrm{~cm}-1$ : (A) natural zeolite sample, NZ; (B) cobalt modified zeolite sample, Z-Co. Operating conditions: 30 mg of zeolite sample, $75 \mathrm{~cm} 3 \mathrm{~min}-1$, inlet concentration of ozone $22000 \mathrm{ppmv}$, at $20{ }^{\circ} \mathrm{C}$.

In agreement with $\mathrm{Wu}$ et al. [28] ozonide $\mathrm{O}_{3}{ }^{-}$species at $800 \mathrm{~cm}^{-1}$, atomic oxygen at 1309 $\mathrm{cm}^{-1}$ and superoxide $\mathrm{O}_{2}^{-}$at $1168 \mathrm{~cm}^{-1}$ are observed. The IR bands at 1057 and $1027 \mathrm{~cm}^{-1}$ are ascribed to molecular ozone adsorption.

At Lewis acid sites ozone could dissociate and generate atomic oxygen species which could contribute to catalytic chain decomposition reactions of ozone $[29,30,35-38]$ and water 
production from $\mathrm{OH}$ groups (see Fig. 7). Z-Co shows a higher capacity towards ozone abatement than NZ. The areas of IR bands associated with superoxide $\mathrm{O}_{2}^{-}$at $1168 \mathrm{~cm}^{-1}$ and atomic oxygen at $1309 \mathrm{~cm}^{-1}$ appearing after ozone decomposition over strong Lewis acidic sites are higher in the case of cobalt modified natural zeolites. The temporal evolution of IR bands are presented in Fig. 9, at $1309 \mathrm{~cm}^{-1}$ (Fig. 9-A), $1168 \mathrm{~cm}^{-1}$ (Fig. 9-B) and $800 \mathrm{~cm}^{-1}$ (Fig. 9-C).
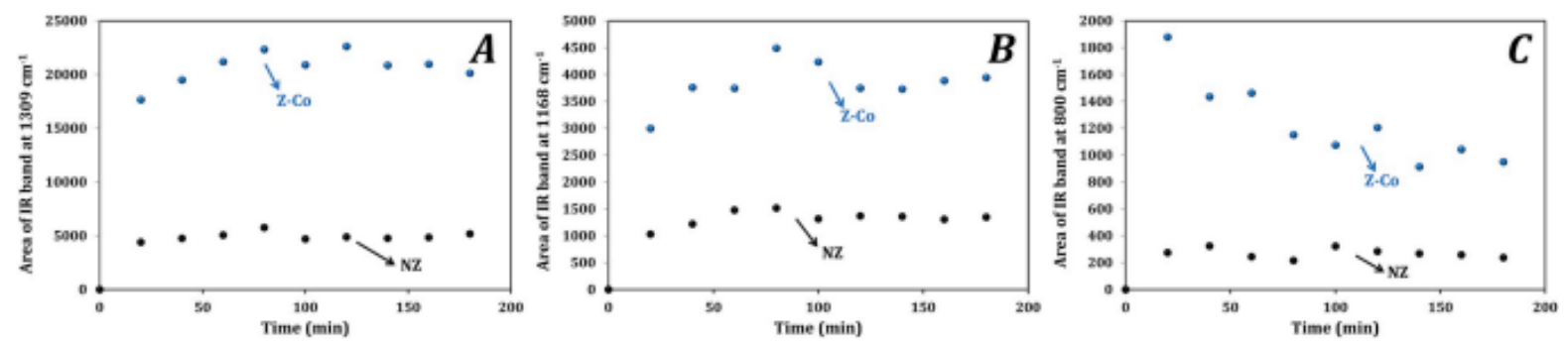

Fig. 9: Temporal evolution of IR bands at $1309 \mathrm{~cm}-1$ (A), $1168 \mathrm{~cm}-1$ (B) and $800 \mathrm{~cm}-1$

(C) for natural zeolite (NZ) and cobalt modified zeolite (Z-Co). Operating conditions: 30 mg of zeolite sample, $75 \mathrm{~cm} 3 \mathrm{~min}-1$, inlet concentration of ozone $22000 \mathrm{ppmv}$, at $20{ }^{\circ} \mathrm{C}$.

It can be seen from Fig. 9 that after 50 minutes a steady state of ozone decomposition reaction is reached at the catalyst surfaces. The species generated from ozone decomposition $\left(\mathrm{O}\right.$ and $\mathrm{O}_{2}^{-}$) are more abundant in the case of Cobalt modified zeolites, indicating that the addition of Co into natural zeolites clearly improves the ozone abatement efficiency.

In the previous analysis, ozone was generated from $\mathrm{O}_{2}$ using an atmospheric pulse injected corona discharge. It has been reported [39] that ozone production using an atmospheric corona discharge can be produced via ground state $\mathrm{O}_{2}$ dissociation into oxygen atom which further reacts with another $\mathrm{O}_{2}$ molecule to give $\mathrm{O}_{3}$. In this case, $\mathrm{O}_{2}$ molecules are dissociated by electron impact.

When ozone is produced from air $\left(\mathrm{N}_{2}+\mathrm{O}_{2}\right) \mathrm{O}_{2}$ molecules could be dissociated by electron impact and also by collisions with excited $\mathrm{N}_{2}$ molecules. Here, the presence of $\mathrm{N}_{2}$ within the 
corona discharge could lead to the formation of nitrogen oxides in the gas phase such as $\mathrm{N}_{2} \mathrm{O}$, $\mathrm{NO}, \mathrm{NO}_{2}$. These molecules can be adsorbed on zeolites active sites. Fig. 10 shows DRIFTS spectra of cobalt modified zeolite (Z-Co) upon contact with gaseous ozone generated from air between 2300 and $750 \mathrm{~cm}^{-1}$.
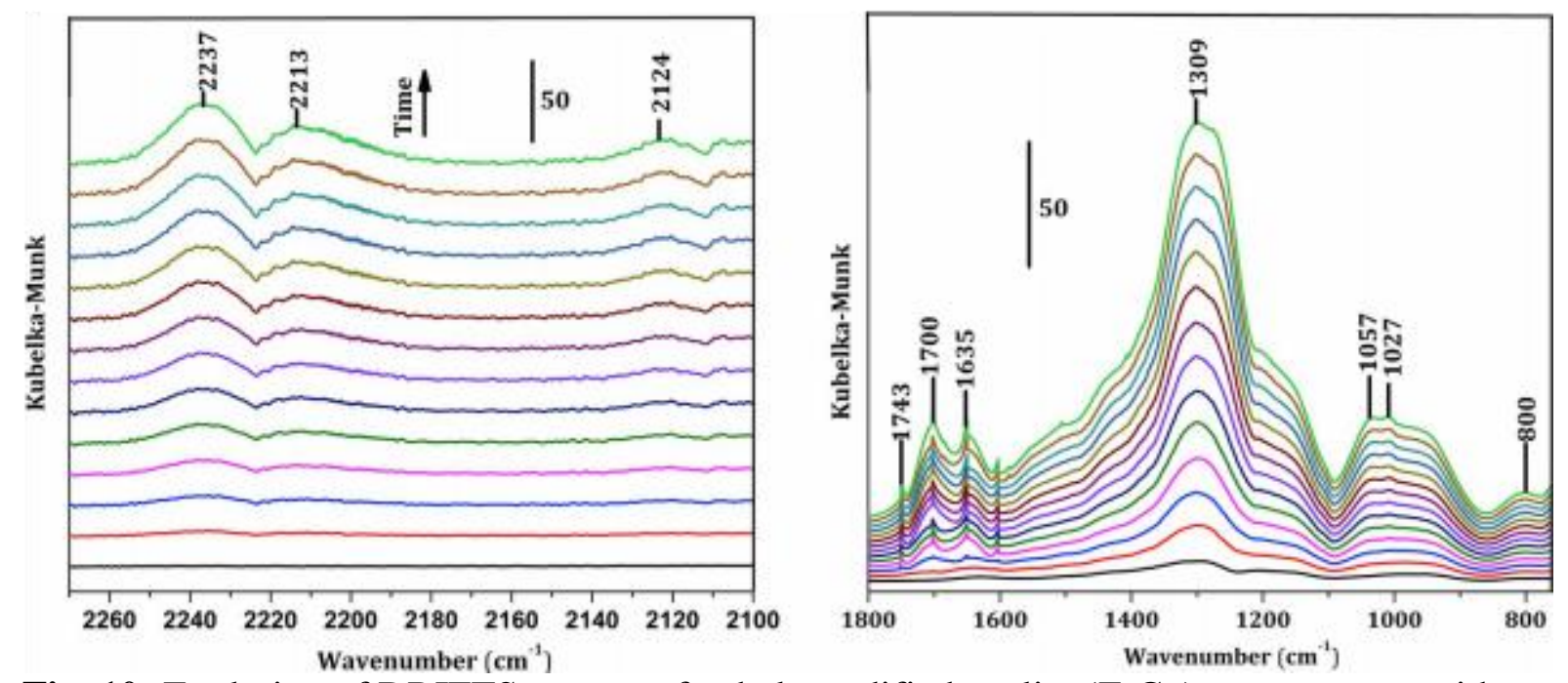

Fig. 10: Evolution of DRIFTS spectra of cobalt modified zeolite (Z-Co) upon contact with gaseous ozone generated from synthetic air between 2300 and $750 \mathrm{~cm}^{-1}$. Operating conditions: $30 \mathrm{mg}$ of zeolite sample, $75 \mathbf{c m}^{3} \mathbf{~ m i n}^{-1}$, inlet concentration of ozone 22000 ppmv, at $20{ }^{\circ} \mathbf{C}$.

Here, new IR bands are observed with respect to the previous study where ozone was generated from pure $\mathrm{O}_{2}$. The bands at 2237 and $2213 \mathrm{~cm}^{-1}$ are ascribed to $\mathrm{N}_{2} \mathrm{O}$ molecules in gas phase $[40,41]$. The band at $2124 \mathrm{~cm}^{-1}$ could be attributed to adsorbed $\mathrm{N}_{2} \mathrm{O}^{+}$species [40,41]. The bands at 1743 and $1700 \mathrm{~cm}^{-1}$ are assigned to adsorbed $\mathrm{N}_{2} \mathrm{O}_{4}$ species [40]. The new nitrous adsorbed species partially occupy the active sites which are needed for adsorbing and further decomposing the $\mathrm{O}_{3}$ molecules. Therefore, due to a diminution of available active sites, the ozone abatement process should be less efficient when ozone is generated from air. In order to prove this hypothesis, the temporal evolution of the IR bands upon the Z-Co 
samples contact gaseous ozone generated from pure $\mathrm{O}_{2}$ and from air are presented in Fig. 11 (Fig. 11-A, variation of IR band at $1309 \mathrm{~cm}^{-1}$; Fig. 11-B variation of IR band at $1168 \mathrm{~cm}^{-1}$; Fig. 11-C variation of IR band at $800 \mathrm{~cm}^{-1}$ ).
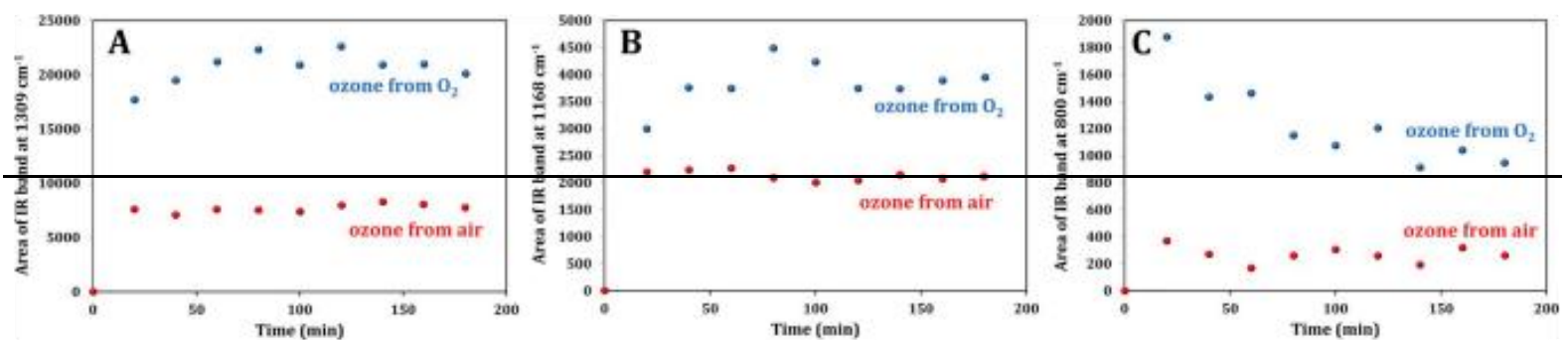

Fig. 11: Temporal evolution of IR bands at 1309 (A), 1168 (B) and $800 \mathrm{~cm}^{-1}$ (C) for Z-Co samples upon contact with gaseous ozone generated from pure $\mathrm{O}_{2}$ and from synthetic air. Operating conditions: $30 \mathrm{mg}$ of zeolite sample, $75 \mathrm{~cm}^{3} \mathrm{~min}^{-1}$, inlet concentration of ozone 22000 ppmv, at $20{ }^{\circ} \mathbf{C}$.

The adsorbed ozone as $\mathrm{O}_{3}{ }^{-}$as well as species generated from ozone decomposition $(\mathrm{O}$ and $\mathrm{O}_{2}^{-}$) are more concentrated at the surface when ozone is generated from pure oxygen. When the ozone is produced from air, the nitrous species created in the gas phase within the corona discharge are adsorbed on the zeolite surface occupying the active sites needed for ozone adsorption and decomposition.

\subsection{Mechanistic and kinetic approximation}

DRIFTS operando study revealed that different mechanism took place for ozone abatement over natural zeolite and cobalt-modified natural zeolite. Schematic representations of these mechanisms are given in Fig. 12. 


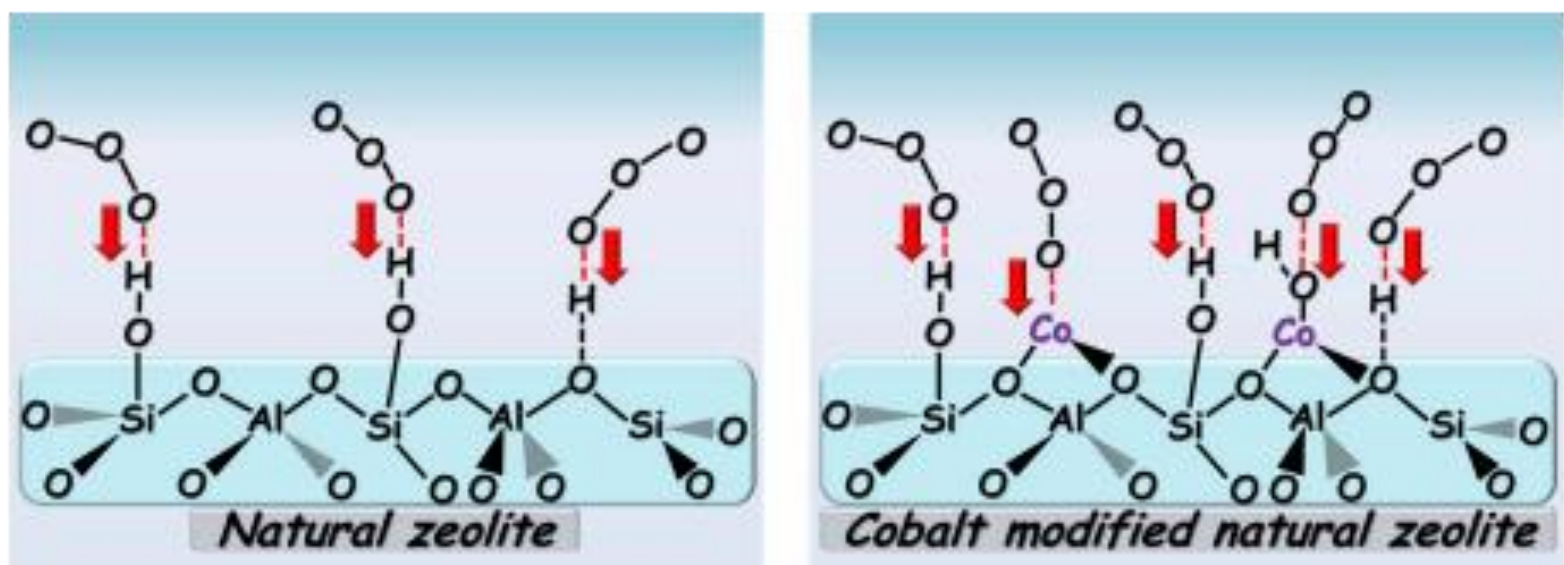

Fig. 12: Schematic representations of ozone abatement mechanism over natural zeolite and cobalt-modified natural zeolite.

In both zeolites, ozone basic molecules are adsorbed and decomposed at strong Lewis acidic sites, leading to decomposition by-products that interact with zeolite $\mathrm{OH}$ groups forming H-bonding. In cobalt-modified natural zeolite, ozone molecules interact with cobalt cations (Lewis acid sites). Over strong Lewis acidic sites (Z-Co) ozone is dissociated and adsorbed atomic oxygen and superoxide species are observed at the Z-Co surface. The latter species could contribute to catalytic chain decomposition reactions of ozone. The new Lewis acidic sites generated from cobalt introduction into the zeolite matrix play a very important role in ozone adsorption and abatement.

\section{Conclusions}

Transition-metal-modified natural zeolites could be effectively used as alternative and low cost catalysts to destroy ozone emissions from working environments after a sequence of chemical and thermal treatments. Cobalt modified natural zeolite enhances ozone removal compare to the parent natural zeolite. A succession of two ion-exchange with ammonium, thermal out-gassing at $350^{\circ} \mathrm{C}$, and impregnation with cobalt ions $\left(0.07 \mathrm{~mol} \mathrm{dm}{ }^{-3}\right)$ followed by thermal out-gassing at $350^{\circ} \mathrm{C}$, is claimed to produce a modified natural zeolite with the 
optimal properties toward the elimination of gaseous ozone at $20^{\circ} \mathrm{C}$. DRIFTS analyses evidence the formation of new active sites on natural zeolite, leading to an increase on ozone gaseous elimination. Ozone abatement over natural and cobalt modified natural zeolite are due to a combined mechanism that includes ozone adsorption and decomposition at strong Lewis acidic sites. DRIFTS results also show that such acidic sites are poisoned by nitrous adsorbed species when ozone is generated from air, reducing zeolite capacity to decompose ozone. In the design of new materials based on the use of zeolitic materials for ozone elimination specially attention should be paid on the nature and strength of active acid sites.

\section{Acknowledgements}

This work was supported by the CONICYT, FONDECYT/Regular under Grant 1130560. F.J. Ulloa expresses his gratitude to the Programa de Maestría en Ingeniería Industrial from Universidad Católica de la Santísima Concepción for providing a master scholarship. F. Azzolina-Jury acknowledges Fondo Especial de Actividades Académicas UCSC 2018-II for its mobility funding.

\section{References}

[1]B. Dhandapani, S.T. Oyama, Appl. Catal. B-Environ. 11 (1997) 129-166.

[2]S. Anand Kumar Varma, M. Srimurali, K. R. Manjula, Int. J. Sci. Res. 2 (2013) 12-13.

[3]American Water Works Association Research Foundation, Compagnie Generale des Eaux,

Ozone in water treatment: application and engineering, Edited by Bruno Langlais,

David A. Reckhow, Deborah R. Brink, Lewis Publishers, CRS Press, Taylor \& Francis Group, Boca Raton, FL, 1991. 
[4]H. Valdés, M. Sánchez-Polo, J. Rivera-Utrilla, C.A. Zaror, Effect of ozone treatment on surface properties of activated carbon, Langmuir, 18 (2002) 2111-2116.

[5]C. Subrahmanyam, D.A. Bulushev, L. Kiwi-Minsker, Appl. Catal. B: Environ, 61(2005) 98-106.

[6]A. Naydenov, R. Stoyanova, D. Mehandjiev, J. Mol. Catal. A-Chem. 98 (1995) 9-14.

[7]K.M. Bulanin, J.C. Lavalley, A.A. Tsyganenko, J. Phys. Chem. B 101 (1997) 2917-2922.

[8]C. Heisig, W. Zhang, S.T. Oyama, Appl. Catal. B-Environ. 14 (1997) 117-129.

[9]K.M Bulanin, J.C. Lavalley, A.A. Tsyganenko, Colloid Surf. A, 101 (1995) 153-158.

[10] A. Alebić-Juretić, T. Cvitaš, L. Klasinc, Chemosphere 41 (2000) 667-670.

[11] D. Mehandjiev, A. Naydenov, G. Ivanov, Appl. Catal. A-Gen. 206 (2001) 13-18.

[12] Z. Hao, D. Cheng, Y. Guo, Y. Liang, Appl. Catal. B-Environ. 33 (2001) 217-222.

[13] S. Alejandro, H. Valdés, C.A. Zaror, J. Adv. Oxid. Technol. 14 (2011) 182-189.

[14] H. Valdés, E. Padilla, C.A. Zaror, Ozone-Sci. Eng. 33 (2011) 279-284.

[15] H. Valdés, S. Alejandro, C.A. Zaror, J. Hazard. Mater. 227-228 (2012) 34-40.

[16] N.J. Abreu, H. Valdés, C.A. Zaror, F. Azzolina-Jury, M. Meléndrez, Microporous Mesoporous Mater. 274 (2019) 138-148.

[17] A. Riquelme, H. Valdés, Ingeniare 24 (2016) 542-557.

[18] V.K. Díez, C.R. Apesteguía, J.I. Di Cosimo, J. Catal. 215 (2003) 220-233.

[19] F. Benaliouche, Y. Boucheffa, P. Ayrault, S. Mignard, P. Magnoux, Microporous Mesoporous Mater. 111 (2008) 80-88.

[20] H. Valdés, V.A. Solar, E.H. Cabrera, A.F. Veloso, C.A. Zaror, Chem. Eng. J. 244 (2014) 117-127.

[21] D. Montgomery, R. Myers, Response Surface Methodology: Process and Product Optimization Using Designed Experiment, $2^{\text {nd }}$ Ed., John Wiley and Sons, Canada, 2002. 
[22] C.-C. Chen, Int. Commun. Heat Mass 38 (2011) 1061-1066.

[23] D.W. Wayne, Applied Nonparametric Statistics, $2^{\text {nd }}$ Ed., Boston: PWS-Kent, 1990.

[24] H.G. Karge, M. Hunger, K. Beyer, Caracterization of zeolites - infrared and nuclear magnetic resonance spectroscopy and X-ray diffraction, In Catalysis and Zeolites: Fundamentals and Application edited by J. Weitkamp, L. Pupe, (2010) 198-326, Berlin, Heidelberg: Springer-Verlag.

[25] A. Vimont, F. Thibault-Starzyk, M. Daturi, Chem. Soc. Rev. 39 (2010) 4928-4950.

[26] B. Kasprzyk-Hodern, M. Ziólek, J. Nawrocki, Appl. Catal. B- Environ. 46 (2003) 639-669.

[27] K.M. Bulanin, J.C. Lavalley, A.A. Tsyganenko, Colloid Surface A 101 (1995) 153158.

[28] J. Wu, T. Su, Y. Jiang, X. Xie, Z. Qin, H. Ji, Appl. Surf. Sci. 412 (2017) 290-305.

[29] K.M. Bulanin, A.V. Alexeev, D.S. Bystrov, J.C. Lavalley, A.A. Tsyganenko, J . Phys. Chem. 98 (1994) 5100-5103.

[30] N. Brodu, M.-H. Manero, C. Andriantsiferana, J.-S. Pic, H. Valdés, Chem. Eng. J. 231 (2013) 281-286.

[31] L. Mariey, J. Lamotte, T. Chevreau, J.C. Lavalley, React. Kinet. Catal. L. 59 (1996) $241-246$.

[32] F. Thibault-Starzyk, F. Maugé, Infrared Spectroscopy, In Characterization of Solid Materials and Heterogeneous Catalysts: From Structure to Surface Reactivity, edited by Michel Che and Jacques C. Vedrine, First Edition. Wiley-VCH Verlag GmbH \& Co. KGaA, 2012.

[33] W. Wu, E. Weitz, Appl. Surf. Sci. 316 (2014) 405-415.

[34] F. Azzolina Jury, I. Polaert, L. Estel, L.B. Pierella, Appl. Catal. A-Gen. 453 (2013) 92-101. 
[35] W. Li, S.T. Oyama, J. Am. Chem. Soc. 120 (1998) 9047-9052.

[36] S.T. Oyama, Catal. Rev.: Sci. Eng. 42 (2000) 279-322.

[37] C.W. Kwong, C.Y.H. Chao, K.S. Hui, M.P. Wan, Environ. Sci. Technol. 42 (2008) 8504-8509.

[38] J. Jia, P. Zhang, L. Chen, Appl. Catal. B-Environ. 189 (2016) 210-218.

[39] M. Simek, M. Clupek, J. Phys. D: Appl. Phys. 35 (2002) 1171-1175.

[40] A. Penkova, K. Hadjiivanov, M. Mihaylov, M. Daturi, J. Saussey, J.-C. Lavalley, Langmuir 20 (2004) 5425-5431.

[41] T.E. Hoost, K.A. Laframboise, K. Otto, Catal. Lett. 33 (1995) 105-116. 


\section{Supplementary information}

\section{Figure captions}

Fig. S1. Analysis of model assumptions. (A) Analysis of normal distribution of studentised residuals. (B) Analysis of homoscedasticity of studentised residuals. (C) Analysis of independence of studentised residuals. (D) Analysis of the goodness-of-fit of the model.

Fig. S2. X-ray powder diffraction patterns of natural zeolite (NZ) and cobalt modified zeolite (Z-Co).

\section{Table captions}

Table S1. Matrix of experiments of the applied D-optimal design including 123 runs, 3 central points, observed $\left(R_{O_{3}}\right)$ and predicted $\left(\hat{R}_{O_{3}}\right)$ values of response for ozone removal (\%) using Z-Mt.

Table S2. Physical-chemical characterisation of natural (NZ) and Co-modified natural zeolite (Z-Co). 


\section{SUPLEMENTARY INFORMATION}

Fig. S1-A

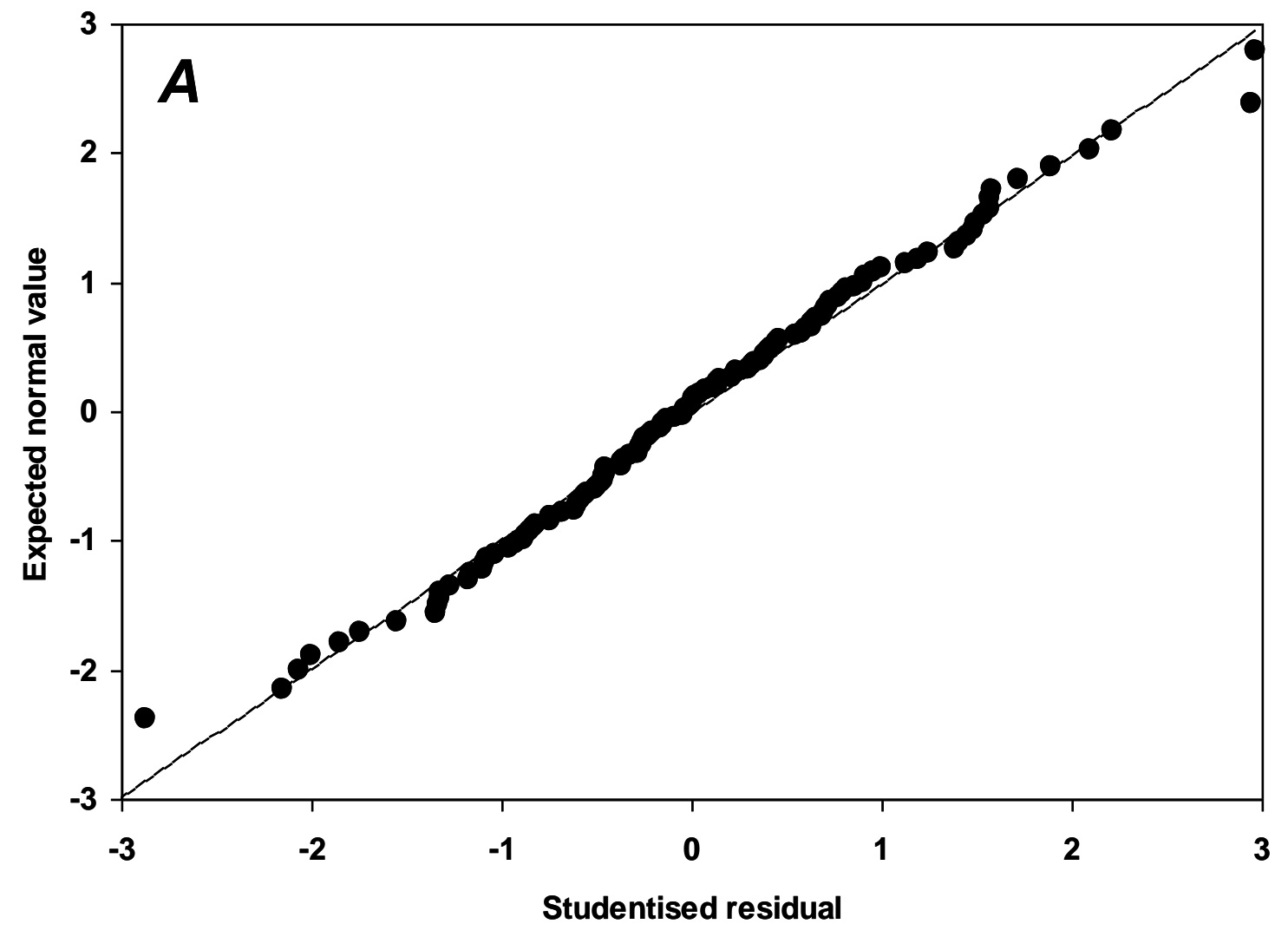


Fig. S1-B

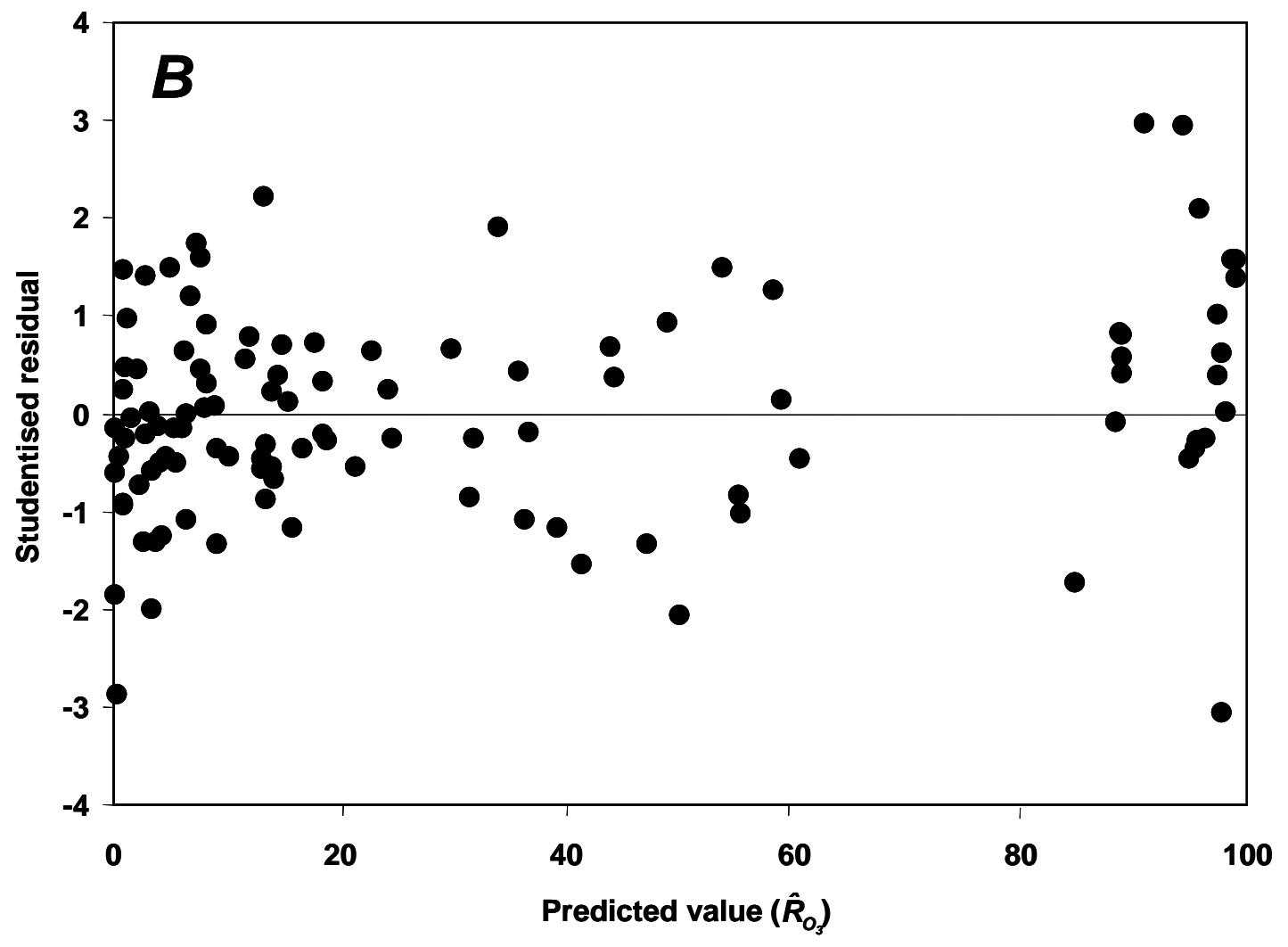


Fig. S1-C

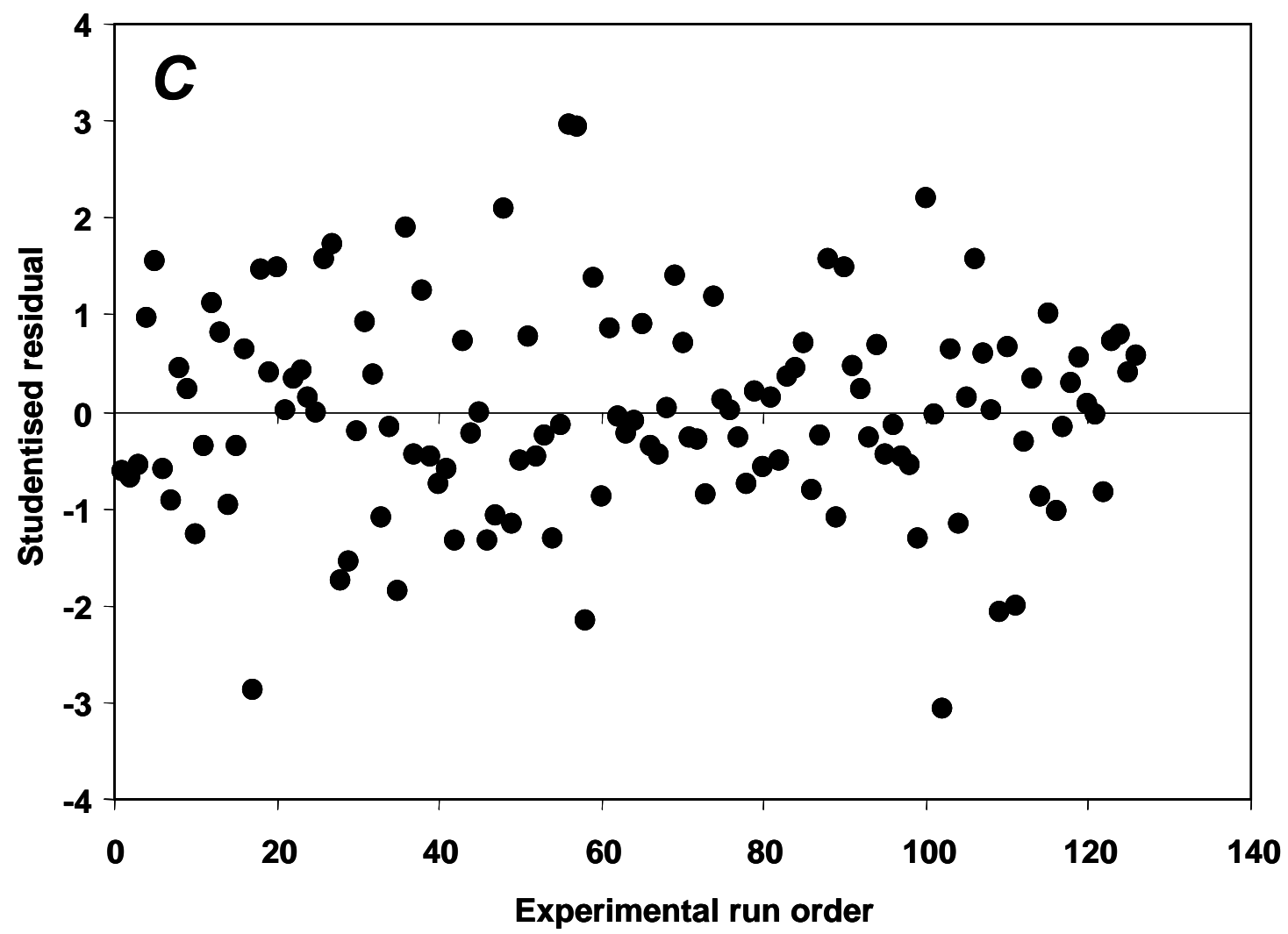


Fig. S1-D

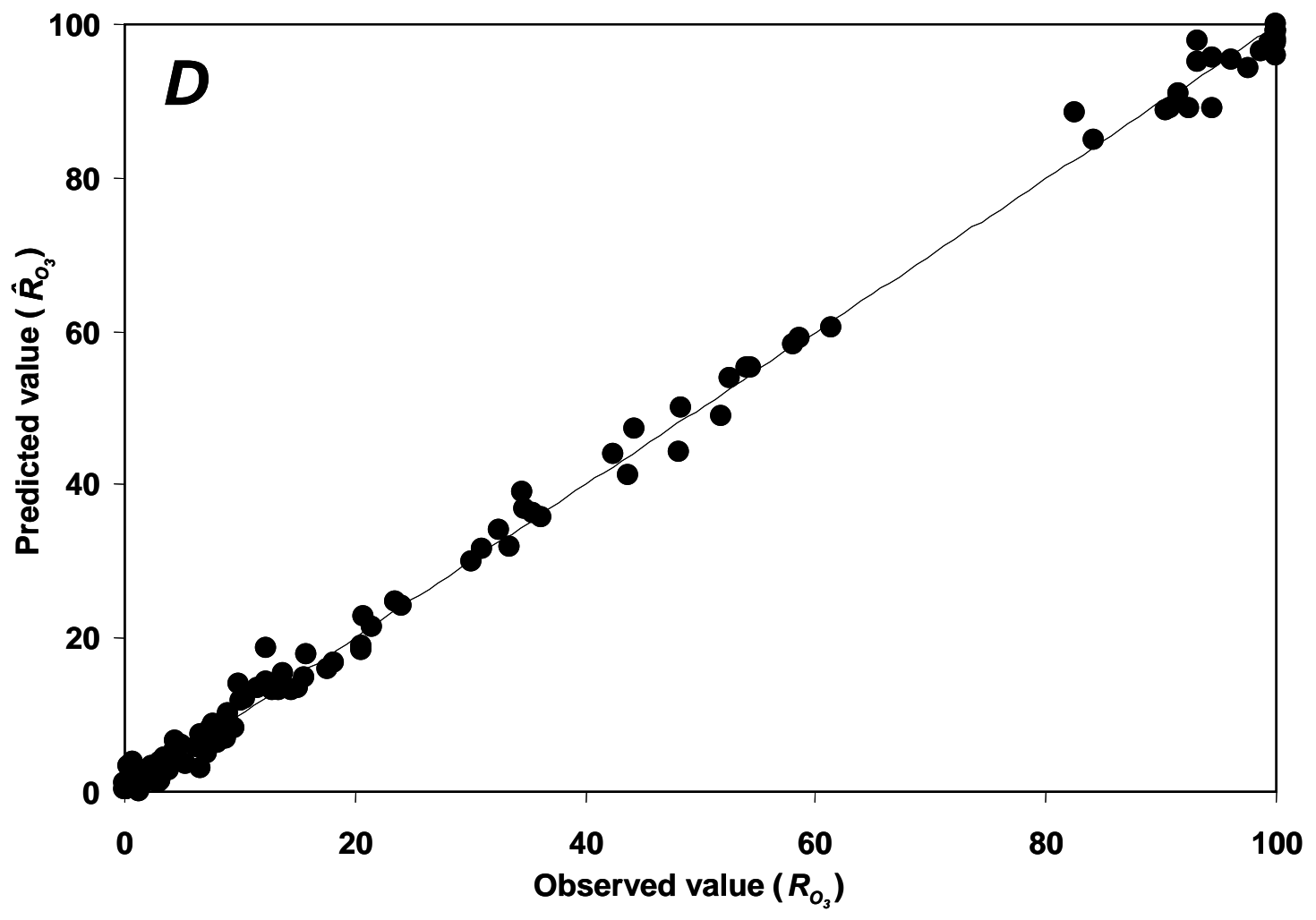

Fig. S1. Analysis of model assumptions. (A) Analysis of normal distribution of studentised residuals. (B) Analysis of homoscedasticity of studentised residuals. (C) Analysis of independence of studentised residuals. (D) Analysis of the goodness-of-fit of the model. 


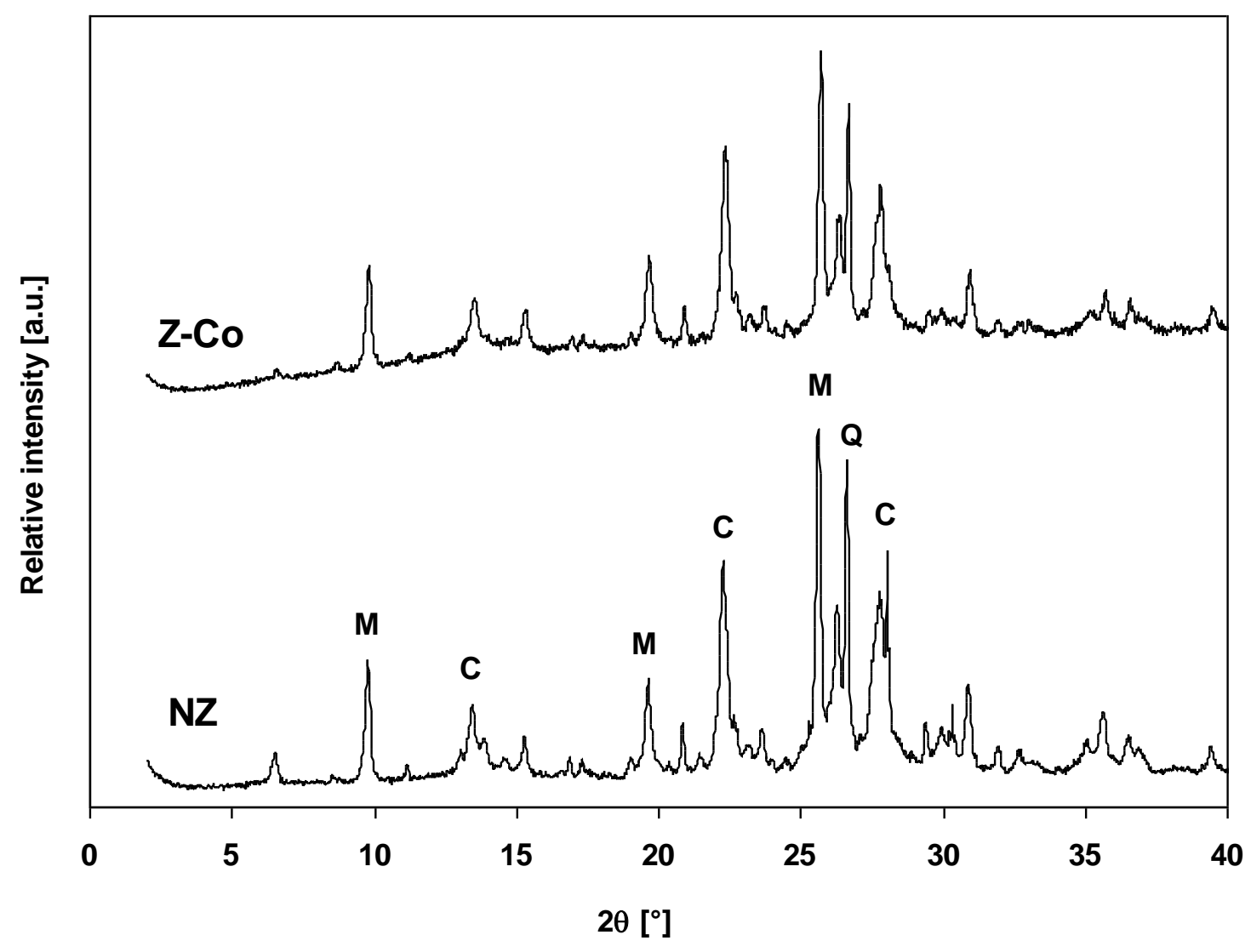

Fig. S2. X-ray powder diffraction patterns of natural zeolite (NZ) and cobalt modified zeolite (Z-Co). 


\section{Table S1}

Matrix of experiments of the applied D-optimal design including 123 runs, 3 central points, observed ( $R_{O_{3}}$ ) and predicted ( $\hat{R}_{O_{3}}$ ) values of response for ozone removal (\%) using Z-Mt.

\begin{tabular}{|c|c|c|c|c|c|c|c|c|c|c|c|c|c|}
\hline Run & $x_{1}$ & $x_{2}$ & $x_{3}$ & $x_{4}$ & $x_{5}$ & $x_{6}$ & $x_{7}$ & $x_{8}$ & $x_{9}$ & $x_{10}$ & $R_{O_{3}}$ & $\hat{R}_{O_{3}}$ & $\varepsilon$ \\
\hline 1 & one & 350 & $\mathrm{Cu}$ & 0.05 & IE & OG & 9000 & 100 & 0.15 & 20 & 0.05 & 0.23 & -0.18 \\
\hline 2 & two & 350 & $\mathrm{Cu}$ & 0.075 & $\mathrm{IE}$ & OG & 11000 & 100 & 0.3 & 20 & 12.36 & 14.24 & -1.88 \\
\hline 3 & one & 550 & $\mathrm{Cu}$ & 0.05 & $\mathrm{IE}$ & $\mathrm{OG}$ & 10000 & 50 & 0.3 & 100 & 9.99 & 13.96 & -3.97 \\
\hline 4 & two & 550 & $\mathrm{Cu}$ & 0.1 & $\mathrm{IE}$ & $O G$ & 9000 & 100 & 0.15 & 100 & 3.1 & 1.31 & 1.79 \\
\hline 5 & one & 350 & $\mathrm{Mn}$ & 0.1 & IE & $\mathrm{OG}$ & 9000 & 75 & 0.15 & 100 & 100 & 103.26 & -3.26 \\
\hline 6 & one & 550 & $\mathrm{Mn}$ & 0.05 & IE & $O G$ & 11000 & 50 & 0.15 & 20 & 5.36 & 3.44 & 1.92 \\
\hline 7 & two & 550 & $\mathrm{Mn}$ & 0.1 & IE & $O G$ & 9000 & 100 & 0.3 & 20 & 0.23 & 0.89 & -0.66 \\
\hline 8 & one & 350 & $\mathrm{Fe}$ & 0.05 & IE & OG & 10000 & 50 & 0.3 & 20 & 1.9 & 2.22 & -0.32 \\
\hline 9 & two & 350 & $\mathrm{Fe}$ & 0.1 & IE & $O G$ & 11000 & 100 & 0.3 & 100 & 24.11 & 24.27 & -0.16 \\
\hline 10 & one & 550 & $\mathrm{Fe}$ & 0.1 & IE & OG & 9000 & 100 & 0.15 & 100 & 3.45 & 4.33 & -0.88 \\
\hline 11 & two & 550 & $\mathrm{Fe}$ & 0.075 & IE & $O G$ & 9000 & 50 & 0.15 & 20 & 18.14 & 16.77 & 1.37 \\
\hline 12 & two & 350 & $\mathrm{Ni}$ & 0.1 & $\mathrm{IE}$ & $\mathrm{OG}$ & 9000 & 50 & 0.15 & 20 & 0.1 & -1.04 & 1.14 \\
\hline 13 & two & 350 & $\mathrm{Ni}$ & 0.05 & $\mathrm{IE}$ & OG & 9000 & 50 & 0.3 & 100 & 90.4 & 88.81 & 1.59 \\
\hline 14 & one & 550 & $\mathrm{Ni}$ & 0.1 & IE & OG & 9000 & 100 & 0.225 & 20 & 0.24 & 0.94 & -0.7 \\
\hline 15 & one & 350 & $\mathrm{Ag}$ & 0.05 & $\mathrm{IE}$ & $\mathrm{OG}$ & 11000 & 100 & 0.3 & 100 & 8.98 & 9.24 & -0.26 \\
\hline 16 & two & 350 & $\mathrm{Ag}$ & 0.1 & IE & OG & 9000 & 50 & 0.15 & 60 & 8.03 & 6.22 & 1.81 \\
\hline 17 & one & 550 & $\mathrm{Ag}$ & 0.1 & IE & $O G$ & 11000 & 50 & 0.225 & 100 & 0.2 & 0.33 & -0.13 \\
\hline 18 & two & 550 & $\mathrm{Ag}$ & 0.1 & IE & $O G$ & 11000 & 100 & 0.15 & 20 & 0.31 & 0.9 & -0.59 \\
\hline 19 & one & 350 & Co & 0.1 & $\mathrm{IE}$ & OG & 9000 & 50 & 0.3 & 100 & 100 & 97.41 & 2.59 \\
\hline 20 & one & 550 & Co & 0.05 & $\mathrm{IE}$ & $\mathrm{OG}$ & 9000 & 100 & 0.3 & 20 & 7.21 & 5.02 & 2.19 \\
\hline 21 & two & 550 & Co & 0.05 & $\mathrm{IE}$ & $\mathrm{OG}$ & 9000 & 50 & 0.15 & 100 & 100 & 101.42 & -1.42 \\
\hline 22 & one & 350 & $\mathrm{Cu}$ & 0.1 & 1 & $O G$ & 11000 & 50 & 0.15 & 100 & 20.58 & 18.52 & 2.06 \\
\hline 23 & two & 350 & $\mathrm{Cu}$ & 0.05 & I & OG & 9000 & 100 & 0.3 & 100 & 36.16 & 35.77 & 0.39 \\
\hline 24 & one & 550 & $\mathrm{Cu}$ & 0.1 & 1 & $\mathrm{OG}$ & 9000 & 100 & 0.3 & 20 & 0.12 & -0.79 & 0.91 \\
\hline 25 & two & 550 & $\mathrm{Cu}$ & 0.05 & 1 & $\mathrm{OG}$ & 11000 & 50 & 0.15 & 20 & 0.23 & -0.65 & 0.88 \\
\hline 26 & one & 350 & $\mathrm{Mn}$ & 0.05 & I & OG & 11000 & 100 & 0.225 & 20 & 8.58 & 7.68 & 0.9 \\
\hline 27 & two & 350 & $\mathrm{Mn}$ & 0.1 & 1 & OG & 11000 & 50 & 0.3 & 20 & 6.68 & 7.36 & -0.68 \\
\hline 28 & one & 550 & $\mathrm{Mn}$ & 0.05 & 1 & $O G$ & 9000 & 50 & 0.3 & 100 & 84.2 & 84.83 & -0.63 \\
\hline 29 & two & 550 & $\mathrm{Mn}$ & 0.1 & 1 & OG & 11000 & 100 & 0.15 & 100 & 43.7 & 41.31 & 2.39 \\
\hline 30 & two & 350 & $\mathrm{Fe}$ & 0.1 & 1 & OG & 9000 & 50 & 0.15 & 100 & 34.79 & 36.72 & -1.93 \\
\hline 31 & one & 550 & $\mathrm{Fe}$ & 0.05 & 1 & $\mathrm{OG}$ & 11000 & 50 & 0.3 & 100 & 51.92 & 48.99 & 2.93 \\
\hline 32 & two & 550 & $\mathrm{Fe}$ & 0.05 & I & OG & 9000 & 100 & 0.225 & 20 & 13.58 & 14.59 & -1.01 \\
\hline 33 & one & 550 & $\mathrm{Ni}$ & 0.05 & 1 & OG & 9000 & 50 & 0.15 & 60 & 35.43 & 36.31 & -0.88 \\
\hline 34 & two & 550 & $\mathrm{Ni}$ & 0.05 & 1 & OG & 11000 & 100 & 0.3 & 20 & 4.89 & 6.04 & -1.15 \\
\hline 35 & one & 350 & $\mathrm{Ag}$ & 0.05 & 1 & $O G$ & 9000 & 50 & 0.3 & 20 & 0.12 & 0.25 & -0.13 \\
\hline 36 & two & 350 & $\mathrm{Ag}$ & 0.05 & 1 & $O G$ & 11000 & 50 & 0.15 & 100 & 32.61 & 33.99 & -1.38 \\
\hline 37 & one & 550 & $\mathrm{Ag}$ & 0.05 & 1 & OG & 10000 & 100 & 0.15 & 20 & 1.41 & 0.54 & 0.87 \\
\hline 38 & two & 550 & $\mathrm{Ag}$ & 0.1 & 1 & OG & 9000 & 75 & 0.3 & 100 & 58.09 & 58.29 & -0.2 \\
\hline
\end{tabular}




\begin{tabular}{|c|c|c|c|c|c|c|c|c|c|c|c|c|c|}
\hline 39 & two & 350 & Co & 0.1 & I & OG & 9000 & 100 & 0.15 & 20 & 12.9 & 13.1 & -0.2 \\
\hline 40 & two & 350 & Co & 0.05 & 1 & $O G$ & 11000 & 75 & 0.3 & 20 & 2.17 & 2.29 & -0.12 \\
\hline 41 & one & 550 & Co & 0.1 & I & $O G$ & 11000 & 50 & 0.15 & 20 & 0.35 & 3.39 & -3.04 \\
\hline 42 & one & 350 & $\mathrm{Cu}$ & 0.1 & IE & C & 9000 & 100 & 0.3 & 100 & 44.3 & 47.15 & -2.85 \\
\hline 43 & two & 550 & $\mathrm{Cu}$ & 0.05 & IE & C & 9000 & 100 & 0.3 & 20 & 0.49 & -1.83 & 2.32 \\
\hline 44 & two & 550 & $\mathrm{Cu}$ & 0.1 & IE & $C$ & 11000 & 50 & 0.15 & 60 & 12.3 & 18.61 & -6.31 \\
\hline 45 & one & 350 & $\mathrm{Mn}$ & 0.1 & $\mathrm{IE}$ & $C$ & 9000 & 50 & 0.3 & 20 & 6.93 & 6.51 & 0.42 \\
\hline 46 & two & 350 & $\mathrm{Mn}$ & 0.1 & $\mathrm{IE}$ & $C$ & 11000 & 100 & 0.15 & 20 & 8.63 & 9.19 & -0.56 \\
\hline 47 & two & 350 & $\mathrm{Mn}$ & 0.05 & IE & $C$ & 11000 & 50 & 0.3 & 100 & 100 & 100.09 & -0.09 \\
\hline 48 & one & 550 & $\mathrm{Mn}$ & 0.05 & IE & $C$ & 9000 & 100 & 0.15 & 100 & 100 & 95.8 & 4.2 \\
\hline 49 & two & 350 & $\mathrm{Fe}$ & 0.05 & IE & $C$ & 11000 & 100 & 0.15 & 100 & 17.68 & 15.91 & 1.77 \\
\hline 50 & two & 350 & $\mathrm{Fe}$ & 0.1 & IE & $C$ & 9000 & 50 & 0.3 & 60 & 6.34 & 5.65 & 0.69 \\
\hline 51 & one & 550 & $\mathrm{Fe}$ & 0.075 & IE & C & 11000 & 100 & 0.3 & 20 & 10.52 & \begin{tabular}{|l|}
11.97 \\
\end{tabular} & -1.45 \\
\hline 52 & one & 350 & $\mathrm{Ni}$ & 0.05 & $\mathrm{IE}$ & $C$ & 9000 & 50 & 0.15 & 100 & 93.23 & 94.95 & -1.72 \\
\hline 53 & two & 550 & $\mathrm{Ni}$ & 0.1 & IE & $C$ & 11000 & 100 & 0.3 & 100 & 98.69 & 96.33 & 2.36 \\
\hline 54 & one & 350 & $\mathrm{Ag}$ & 0.05 & IE & $C$ & 11000 & 50 & 0.15 & 20 & 3.08 & 3.8 & -0.72 \\
\hline 55 & two & 350 & $\mathrm{Ag}$ & 0.05 & IE & $C$ & 9000 & 100 & 0.225 & 20 & 0.71 & 3.9 & -3.19 \\
\hline 56 & two & 550 & $\mathrm{Ag}$ & 0.075 & IE & $C$ & 9000 & 50 & 0.3 & 100 & 91.54 & 90.93 & 0.61 \\
\hline 57 & one & 350 & Co & 0.1 & IE & $C$ & 11000 & 100 & 0.15 & 100 & 97.6 & 94.36 & 3.24 \\
\hline 58 & two & 350 & Co & 0.05 & $\mathrm{IE}$ & $C$ & 9000 & 75 & 0.3 & 100 & 100 & 101.56 & -1.56 \\
\hline 59 & one & 550 & Co & 0.05 & IE & $C$ & 11000 & 50 & 0.3 & 100 & 100 & 99.11 & 0.89 \\
\hline 60 & one & 550 & Co & 0.1 & IE & $C$ & 9000 & 75 & 0.15 & 20 & 11.63 & 13.57 & -1.94 \\
\hline 61 & two & 550 & $\mathrm{Cu}$ & 0.1 & IE & C & 11000 & 50 & 0.3 & 20 & 3.73 & -0.16 & 3.89 \\
\hline 62 & one & 350 & $\mathrm{Cu}$ & 0.05 & 1 & $C$ & 11000 & 50 & 0.3 & 20 & 0.85 & 1.7 & -0.85 \\
\hline 63 & one & 550 & $\mathrm{Cu}$ & 0.1 & 1 & $C$ & 9000 & 50 & 0.15 & 100 & 6.7 & 2.9 & 3.8 \\
\hline 64 & one & 550 & $\mathrm{Mn}$ & 0.05 & 1 & $C$ & 11000 & 100 & 0.15 & 100 & 82.51 & 88.41 & -5.9 \\
\hline 65 & two & 350 & $\mathrm{Mn}$ & 0.05 & 1 & $C$ & 9000 & 50 & 0.15 & 20 & 9.49 & 8.22 & 1.27 \\
\hline 66 & one & 550 & $\mathrm{Mn}$ & 0.1 & 1 & $C$ & 11000 & 50 & 0.15 & 100 & 96.11 & 95.46 & 0.65 \\
\hline 67 & two & 550 & $\mathrm{Fe}$ & 0.05 & 1 & C & 11000 & 75 & 0.3 & 20 & 4.23 & 4.62 & -0.39 \\
\hline 68 & one & 350 & $\mathrm{Fe}$ & 0.1 & 1 & $C$ & 11000 & 100 & 0.15 & 60 & 8.22 & 8.09 & 0.13 \\
\hline 69 & one & 550 & $\mathrm{Fe}$ & 0.05 & 1 & $C$ & 9000 & 50 & 0.15 & 20 & 2.11 & 2.87 & -0.76 \\
\hline 70 & two & 550 & $\mathrm{Ni}$ & 0.1 & I & $C$ & 10000 & 100 & 0.3 & 100 & 98.98 & 101.62 & -2.64 \\
\hline 71 & one & 350 & $\mathrm{Ni}$ & 0.05 & 1 & $C$ & 9000 & 100 & 0.3 & 20 & 20.61 & 18.82 & 1.79 \\
\hline 72 & one & 350 & $\mathrm{Ni}$ & 0.1 & 1 & $C$ & 11000 & 50 & 0.3 & 100 & 94.57 & 95.74 & -1.17 \\
\hline 73 & two & 350 & $\mathrm{Ni}$ & 0.1 & 1 & $C$ & 9000 & 100 & 0.15 & 100 & 54.39 & 55.29 & -0.9 \\
\hline 74 & one & 550 & $\mathrm{Ni}$ & 0.1 & 1 & C & 11000 & 100 & 0.15 & 20 & 8.87 & 6.77 & 2.1 \\
\hline 75 & two & 550 & $\mathrm{Ni}$ & 0.1 & 1 & $C$ & 9000 & 50 & 0.3 & 20 & 13.71 & 15.4 & -1.69 \\
\hline 76 & two & 550 & $\mathrm{Ni}$ & 0.05 & I & $C$ & 11000 & 50 & 0.225 & 100 & 100 & 98.13 & 1.87 \\
\hline 77 & one & 350 & $\mathrm{Ag}$ & 0.05 & 1 & C & 9000 & 75 & 0.15 & 100 & 33.51 & 31.78 & 1.73 \\
\hline 78 & two & 350 & $\mathrm{Ag}$ & 0.1 & 1 & $C$ & 11000 & 100 & 0.3 & 20 & 0.42 & -1.83 & 2.25 \\
\hline 79 & one & 550 & $\mathrm{Ag}$ & 0.05 & 1 & C & 11000 & 100 & 0.3 & 60 & 13.3 & 13.98 & -0.68 \\
\hline 80 & one & 350 & Co & 0.075 & 1 & $C$ & 9000 & 50 & 0.15 & 20 & 13.43 & 13.14 & 0.29 \\
\hline 81 & one & 550 & Co & 0.1 & 1 & $C$ & 9000 & 100 & 0.3 & 100 & 100 & 101.21 & -1.21 \\
\hline 82 & two & 550 & Co & 0.05 & 1 & $C$ & 11000 & 100 & 0.15 & 20 & 4.34 & 4.06 & 0.28 \\
\hline 83 & one & 350 & $\mathrm{Cu}$ & 0.05 & IE & $\mathrm{R}$ & 11000 & 100 & 0.3 & 100 & 48.2 & 44.24 & 3.96 \\
\hline
\end{tabular}




\begin{tabular}{|c|c|c|c|c|c|c|c|c|c|c|c|c|c|}
\hline 84 & two & 350 & $\mathrm{Cu}$ & 0.1 & IE & $\mathrm{R}$ & 9000 & 50 & 0.3 & 20 & 8.62 & 7.82 & 0.8 \\
\hline 85 & two & 350 & $\mathrm{Cu}$ & 0.05 & IE & $R$ & 9000 & 50 & 0.15 & 100 & 15.66 & 14.96 & 0.7 \\
\hline 86 & one & 550 & $\mathrm{Cu}$ & 0.1 & IE & $R$ & 11000 & 50 & 0.15 & 20 & 0.56 & -1.17 & 1.73 \\
\hline 87 & one & 350 & $\mathrm{Mn}$ & 0.05 & IE & $\mathrm{R}$ & 9000 & 100 & 0.3 & 20 & 0.05 & 1.07 & -1.02 \\
\hline 88 & one & 550 & $\mathrm{Mn}$ & 0.1 & IE & $\mathrm{R}$ & 11000 & 100 & 0.3 & 100 & 100 & 98.78 & 1.22 \\
\hline 89 & two & 550 & $\mathrm{Mn}$ & 0.1 & IE & $\mathrm{R}$ & 9000 & 50 & 0.225 & 20 & 4.38 & 6.55 & -2.17 \\
\hline 90 & one & 350 & $\mathrm{Fe}$ & 0.1 & $\mathrm{IE}$ & $\mathrm{R}$ & 11000 & 50 & 0.225 & 100 & 52.53 & 53.84 & -1.31 \\
\hline 91 & two & 350 & $\mathrm{Fe}$ & 0.1 & $\mathrm{IE}$ & $\mathrm{R}$ & 9000 & 100 & 0.15 & 20 & 2.89 & 1.08 & 1.81 \\
\hline 92 & one & 550 & $\mathrm{Fe}$ & 0.05 & IE & $\mathrm{R}$ & 11000 & 100 & 0.15 & 20 & 0.62 & 0.98 & -0.36 \\
\hline 93 & two & 550 & $\mathrm{Fe}$ & 0.05 & IE & $R$ & 9000 & 50 & 0.3 & 100 & 23.45 & 24.61 & -1.16 \\
\hline 94 & one & 350 & $\mathrm{Ni}$ & 0.05 & $\mathrm{IE}$ & $\mathrm{R}$ & 11000 & 100 & 0.15 & 100 & 42.51 & 43.96 & -1.45 \\
\hline 95 & one & 550 & $\mathrm{Ni}$ & 0.05 & $\mathrm{IE}$ & $\mathrm{R}$ & 11000 & 50 & 0.3 & 20 & 9.06 & 10.2 & -1.14 \\
\hline 96 & two & 550 & $\mathrm{Ni}$ & 0.05 & IE & $\mathrm{R}$ & 9000 & 100 & 0.15 & 20 & 4.49 & 5.37 & -0.88 \\
\hline 97 & two & 550 & $\mathrm{Ni}$ & 0.1 & IE & $\mathrm{R}$ & 10000 & 50 & 0.15 & 100 & 61.35 & 60.55 & 0.8 \\
\hline 98 & one & 550 & $\mathrm{Ag}$ & 0.1 & IE & $\mathrm{R}$ & 9000 & 100 & 0.3 & 20 & 21.58 & 21.35 & 0.23 \\
\hline 99 & one & 550 & $\mathrm{Ag}$ & 0.05 & IE & $\mathrm{R}$ & 9000 & 50 & 0.15 & 100 & 3.77 & 2.71 & 1.06 \\
\hline 100 & two & 550 & $\mathrm{Ag}$ & 0.05 & $\mathrm{IE}$ & $R$ & 11000 & 50 & 0.3 & 20 & 14.46 & 13.29 & 1.17 \\
\hline 101 & two & 350 & Co & 0.05 & $\mathrm{IE}$ & $\mathrm{R}$ & 11000 & 50 & 0.15 & 20 & 0.34 & -0.32 & 0.66 \\
\hline 102 & two & 550 & Co & 0.075 & IE & $\mathrm{R}$ & 11000 & 100 & 0.3 & 100 & 93.2 & 97.87 & -4.67 \\
\hline 103 & two & 350 & $\mathrm{Cu}$ & 0.1 & 1 & $\mathrm{R}$ & 10000 & 100 & 0.15 & 20 & 20.77 & 22.92 & -2.15 \\
\hline 104 & one & 550 & $\mathrm{Cu}$ & 0.075 & 1 & $R$ & 9000 & 75 & 0.225 & 60 & 34.5 & 39.12 & -4.62 \\
\hline 105 & two & 550 & $\mathrm{Cu}$ & 0.1 & 1 & $\mathrm{R}$ & 11000 & 50 & 0.3 & 100 & 58.57 & 59 & -0.43 \\
\hline 106 & one & 350 & $\mathrm{Mn}$ & 0.05 & 1 & $R$ & 11000 & 50 & 0.15 & 100 & 100 & 99.07 & 0.93 \\
\hline 107 & two & 350 & $\mathrm{Mn}$ & 0.1 & 1 & $\mathrm{R}$ & 9000 & 100 & 0.3 & 100 & 100 & 97.92 & 2.08 \\
\hline 108 & one & 550 & $\mathrm{Mn}$ & 0.1 & 1 & $\mathrm{R}$ & 9000 & 100 & 0.15 & 20 & 3.8 & 3.24 & 0.56 \\
\hline 109 & two & 550 & $\mathrm{Mn}$ & 0.05 & 1 & $R$ & 10000 & 100 & 0.15 & 100 & 48.38 & 49.97 & -1.59 \\
\hline 110 & one & 350 & $\mathrm{Fe}$ & 0.05 & 1 & $\mathrm{R}$ & 9000 & 100 & 0.3 & 100 & 30.21 & 29.88 & 0.33 \\
\hline 111 & two & 350 & $\mathrm{Fe}$ & 0.05 & I & $\mathrm{R}$ & 11000 & 50 & 0.3 & 20 & 2.34 & 3.35 & -1.01 \\
\hline 112 & one & 550 & $\mathrm{Fe}$ & 0.1 & 1 & $R$ & 9000 & 50 & 0.3 & 20 & 15.15 & 13.46 & 1.69 \\
\hline 113 & one & 350 & $\mathrm{Ni}$ & 0.1 & I & $\mathrm{R}$ & 9000 & 50 & 0.15 & 20 & 0.59 & -0.61 & 1.2 \\
\hline 114 & two & 350 & $\mathrm{Ni}$ & 0.1 & 1 & $R$ & 11000 & 100 & 0.3 & 60 & 31.02 & 31.52 & -0.5 \\
\hline 115 & one & 550 & $\mathrm{Ni}$ & 0.05 & I & $R$ & 9000 & 100 & 0.3 & 100 & 99.49 & 97.54 & 1.95 \\
\hline 116 & one & 350 & $\mathrm{Ag}$ & 0.1 & I & $\mathrm{R}$ & 10000 & 50 & 0.3 & 100 & 54 & 55.35 & -1.35 \\
\hline 117 & two & 350 & $\mathrm{Ag}$ & 0.05 & I & $R$ & 11000 & 100 & 0.15 & 20 & 1.32 & 0.1 & 1.22 \\
\hline 118 & one & 550 & $\mathrm{Ag}$ & 0.1 & 1 & $\mathrm{R}$ & 11000 & 100 & 0.15 & 100 & 7.58 & 8.21 & -0.63 \\
\hline 119 & two & 550 & $\mathrm{Ag}$ & 0.1 & I & $\mathrm{R}$ & 9000 & 50 & 0.15 & 20 & 10.03 & 11.73 & -1.7 \\
\hline 120 & one & 350 & Co & 0.1 & 1 & $\mathrm{R}$ & 11000 & 100 & 0.3 & 20 & 7.72 & 8.91 & -1.19 \\
\hline 121 & one & 350 & Co & 0.05 & I & $R$ & 9000 & 100 & 0.15 & 100 & 100 & 101.82 & -1.82 \\
\hline 122 & two & 350 & Co & 0.1 & I & $R$ & 11000 & 50 & 0.15 & 100 & 100 & 101.24 & -1.24 \\
\hline 123 & two & 550 & Co & 0.05 & 1 & $\mathrm{R}$ & 9000 & 50 & 0.3 & 20 & 15.76 & 17.87 & -2.11 \\
\hline 124 & two & 550 & Co & 0.075 & 1 & $R$ & 10000 & 75 & 0.225 & 60 & 94.51 & 89.11 & 5.4 \\
\hline 125 & two & 550 & Co & 0.075 & 1 & $\mathrm{R}$ & 10000 & 75 & 0.225 & 60 & 90.76 & 89.1 & 1.66 \\
\hline 126 & two & 550 & Co & 0.075 & I & $\mathrm{R}$ & 10000 & 75 & 0.225 & 60 & 92.4 & 89.1 & 3.3 \\
\hline
\end{tabular}

lon-exchange (IE), Impregnation (I), Out-Gassing (OG), Calcination (C), Reduction (R) 


\section{Table S2}

Physical-chemical characterisation of natural (NZ) and Co-modified natural zeolite (Z-Co).

\begin{tabular}{|c|c|c|}
\hline Properties & NZ & Z-Co \\
\hline$S_{N 2}\left(m^{2} g^{-1}\right)^{a}$ & 281 & 209 \\
\hline Total volume of pores $\left(\mathrm{cm}^{3} \mathrm{~g}^{-1}\right)^{a}$ & 0.24 & 0.12 \\
\hline Micropore volume $\left(\mathrm{cm}^{3} \mathrm{~g}^{-1}\right)^{a}$ & 0.072 & 0.033 \\
\hline Average pore size [nm] & 3.4 & 2.3 \\
\hline $\mathrm{Si} / \mathrm{Al}^{\mathrm{b}}$ & 5.05 & 5.06 \\
\hline $\mathrm{SiO}_{2}^{b}$ & 72.97 & 69.90 \\
\hline $\mathrm{Al}_{2} \mathrm{O}_{3}{ }^{\mathrm{b}}$ & 14.45 & 13.79 \\
\hline $\mathrm{CaO}^{\mathrm{b}}$ & 5.68 & 4.36 \\
\hline $\mathrm{Fe}_{2} \mathrm{O}_{3}{ }^{\mathrm{b}}$ & 2.53 & 2.62 \\
\hline $\mathrm{Na}_{2} \mathrm{O}^{\mathrm{b}}$ & 2.15 & 0.33 \\
\hline $\mathrm{K}_{2} \mathrm{O}^{\mathrm{b}}$ & 0.9 & 0.49 \\
\hline $\mathrm{MgO}^{\mathrm{b}}$ & 0.59 & 0.30 \\
\hline $\mathrm{TiO}_{2}{ }^{\mathrm{b}}$ & 0.48 & 0.53 \\
\hline $\mathrm{SO}_{3}{ }^{b}$ & 0.08 & 0.07 \\
\hline $\mathrm{P}_{2} \mathrm{O}_{5}{ }^{\mathrm{b}}$ & 0.05 & 0.07 \\
\hline $\mathrm{MnO}^{\mathrm{b}}$ & 0.05 & 0.05 \\
\hline $\mathrm{SrO}^{\mathrm{b}}$ & 0.04 & 0.05 \\
\hline $\mathrm{ZrO}_{2}{ }^{\mathrm{b}}$ & 0.02 & 0.02 \\
\hline $\mathrm{Co}_{2} \mathrm{O}_{3}{ }^{\mathrm{b}}$ & 0 & 7.33 \\
\hline
\end{tabular}

a Determined by nitrogen adsorption-desorption isotherm at $77 \mathrm{~K}$

b Determined by $\mathrm{X}$-ray fluorescence 